\title{
Apple Pomace as Potential Source of Natural Active Compounds*
}

\author{
Authors \\ Katharina Waldbauer, Ruxandra McKinnon, Brigitte Kopp \\ Affiliation \\ Department of Pharmacognosy, University of Vienna, Vienna, \\ Austria \\ Key words \\ Malus domestica, Rosaceae, apple pomace, fruit-derived com- \\ pounds, pectin, polyphenols, polysaccharides, triterpenoids \\ received February 12, 2017 \\ revised May 15, 2017 \\ accepted May 17, 2017 \\ Bibliography \\ DOI https://doi.org/10.1055/s-0043-111898 \\ Published online July 12, 2017 | Planta Med 2017; 83: 994- \\ 1010 @ Georg Thieme Verlag KG Stuttgart · New York I \\ ISSN 0032-0943 \\ Correspondence \\ Dr. Ruxandra McKinnon \\ Department of Pharmacognosy, University of Vienna \\ Althanstrasse 14, 1090 Vienna, Austria \\ Phone: + 447961801214 , Fax: + 43142779552 \\ ruxandra.mckinnon@gmail.com
}

\section{ABSTRACT}

Apple pomace is a waste product of the apple manufacturing industry that has been in the focus of life sciences as it represents a low-cost source of fruit-derived compounds. High fruit consumption is associated with beneficial health effects, and therefore, apple pomace and its constituents raise therapeutic interest. The present work reviews (i) the chemical constituents of apple pomace, (ii) optimized extraction methods of apple pomace compounds, and (iii) biological activities of apple pomace. Current evidence of apple pomace influence on digestion and metabolism, cholesterol and triglyceride homeostasis, diabetes, and sex hormones is summarized. Furthermore, studies regarding its antioxidative, anti-inflammatory, antiproliferative, antibacterial and antiviral effects are presented. The review concludes that apple pomace is an underutilized waste product of the apple industry with the potential of being processed for its nutritional and pharmaceutical value.

\section{Introduction}

The average annual apple harvest of the European Union is about 10 million tons, with Poland, France, Italy, and Germany as the most productive countries [1]. The majority of the harvest is represented by table apples, which are used for direct consumption or juice production, while tannin-rich cider apples make up 15$40 \%$ of the harvest [2].

Apple pomace is an industrial waste product of apple manufacturing companies. Wet pomace generated by juicing and cider pressing represents up to $25 \%$ of the fresh fruit weight. In 2014 , more than three million tons of apples were used for processing [3], of which about 800000 tons of apple pomace might have accrued. Therefore, profitable ways of disposal or a value added use is of economic and environmental interest.

Scientists of various disciplines have been addressing the subject of apple pomace and a broad research field has developed over the years. This review focuses on the life science aspects of apple pomace research and on literature published in the past five years. In particular, the chemical composition of apple pomace and biological activities mediated by apple pomace extracts and isolated compounds are reviewed.

\section{Composition of Apple Pomace}

\section{Chemical constituents}

Apple pomace consists of apple peels, leftover flesh, core with seeds, and stems. The moisture content after pressing is about $70-85 \%$ [4-7] and makes the pomace prone to microbial infestation. This can be used in the field of solid-state fermentation but should be avoided when intended for other applications. A reduction of water content to less than $10 \%$ should be performed immediately to sustain adequate pomace quality and storage stability [8]. Fresh apple pomace showed the highest moisture content of five investigated fruit pomaces but the shortest drying period to reach equilibrium moisture content. The drying kinetic follows the mathematical models of Midilli et al. or Page et al. [4,9]. Dry-

* This study is dedicated to Professor Dr. Max Wichtl in recognition of his outstanding contribution to pharmacognosy research. 


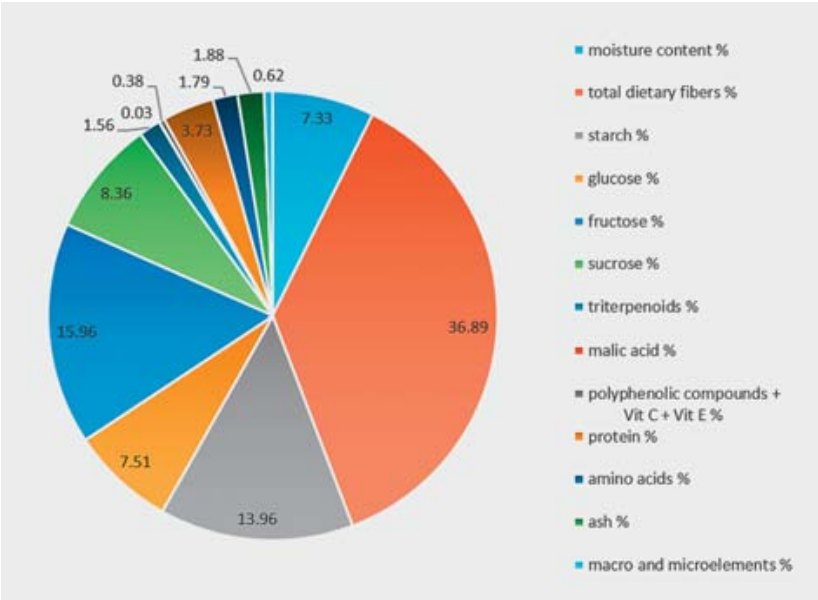

- Fig. 1 Approximate composition of dried apple pomace. Data provided by studies of different pomace sources $[5,6,8,13,14,16$, $22,26,37,54,56,55]$ were partly averaged and normalized to $100 \%$.

ing rates linearly increase with the reduction of pomace layer thickness and temperature rise. The latter also leads to a reduction of equilibrium moisture content at the endpoint of the drying process [9]. These variations influence the composition and number of chemical constituents in apple pomace such as apple pectin [10] and selected polyphenols [8]. However, the originating apple cultivar and seasonal or environmental conditions during apple growth are the major factors that mediate the presence and content of compounds in apple pomace $[11,12]$. After drying, the moisture content is around $10 \%[13,14]$ but can be up to $20 \%$ [15], depending on the drying method.

The approximate composition of dry apple pomace is shown in - Fig. 1 and includes, dietary fibers, starch, glucose, fructose, sucrose, triterpenoids, malic acid, polyphenolic compounds, vitamin $\mathrm{C}$, vitamin $\mathrm{E}$, proteins, amino acids, macro- and microelements, and ash.

The chemical structures of compounds are presented in - Figs. 2-4.

\section{Dietary fibers}

The major part per weight of dry apple pomace is made up by components that are indigestible for the human enzyme system and are therefore called dietary fibers ( $\bullet$ Fig. 1 ). The analysis of pomaces from 11 apple cultivars showed that the average content was 43.6\% [16]. According to their dissolution behavior in water, dietary fibers are divided into soluble dietary fibers and insoluble dietary fibers [17]. Two-thirds of the apple's fibers refer to the insoluble group [16], which comprises cellulose ( $\beta$-1,4-glycosidic linked glucoses), hemicelluloses (xyloglucan, galactomannan and glucuronarabinoxylan), and lignin (polymerized coniferyl, sinapyl and p-coumaryl alcohols) [17].

Apple pectin ( $\triangleright$ Fig. 2), the main component of the soluble dietary fibers, is a three-dimensional macromolecule for which a smooth chain-hairy chain structure model was developed [18].
The smooth chains consist of homogalacturonan ( $\triangleright$ Fig. 2 [1a]), built up from up to $100 \alpha$-1,4-glycosidic linked D-galacturonic acid moieties that could be methyl-esterified at C-6 or acetylated at C-2 and/or C-3. Xylogalacturonan ( Fig. 2 [1b]), rhamnogalacturonan I ( $\vee$ Fig. 2 [1c]), and rhamnogalacturonan II ( Fig. 2 [1d]) form the hairy regions of the macromolecule. These are predominantly located at the start and the end of the smooth chains. Structural elements polymerize, as the free carboxyl groups of the galacturonic acid moieties from different chains could form salts with divalent cations or uronyl esters with a hydroxyl moiety from a different chain. Furthermore, free hydroxyl groups may form esters with 5,5'-diferulic acid or boric acid as a polymerizing step. Thus, the amount of methyl-esterification and the number of hairy chains, as well as the degree of polymerization, lead to differences in molecular weight and determine the three-dimensional expansion of the pectin macromolecule. This results in the varying physical properties known for apple pectin [19]. The increase of the grade of methylesterification requires more acid to be added for gelling. This in turn results in a gel that is more stable against thermal influences [20]. In the intact fruit, pectin is predominantly bound to other cell wall structures such as cellulose and hemicelluloses via calcium salts. For pectin extraction, these bindings must be cleaved, and thereby, the macromolecule partially degrades. Adapted extraction and purification conditions provide pectin with designated physical properties (e.g., swelling capacity or oil retention) [21].

\section{Starch}

Beside indigestible glycosidic polymers, apple pomace contains about 14\% starch [22]. Unripe apples have higher starch contents, which then degrade during apple maturation, increasing the sweetness and softness of apples [23]. This explains the low content of intact starch in apple pomace. The apple industry monitors the starch index for the determination of the optimal harvest time for each individual apple cultivar [24]. Apparently, apple starch is built up from approximately $40-48 \%$ amylose [25].

\section{Mono- and disaccharides}

Mono- and disaccharides account nearly the same share per weight in apple pomace as the total glycosidic polymer fraction ( $\triangleright$ Fig. 1). An investigation of pomaces from 26 cultivars observed proportions of $18-31 \%$ fructose, $3.4-24 \%$ sucrose, and $2.5-$ $12.4 \%$ glucose per absolute weight of dry apple pomace [26]. Another study of 11 cultivars measured average contents of $12.7 \%$ glucose, $17.9 \%$ fructose, and $7.0 \%$ sucrose [16]. Sucrose was the most variable component in amount as the variation coefficient calculated from the contents in the 11 cultivars was $73.4 \%$. A study using an NMR-based method for quantitative determination reported constant relative proportions in four cultivars, which was fructose $>$ glucose $>$ sucrose [27].

\section{Volatile compounds}

The typical apple aroma is made up of more than 250 volatile substances that have been identified in apples [28]. They reach peak concentrations prior to full maturation of the fruit and are mainly biosynthesized via $\beta$-oxidation of fatty acids, leading to the formation of alcohols and acyl-coenzyme A, a precursor for ester forma- 


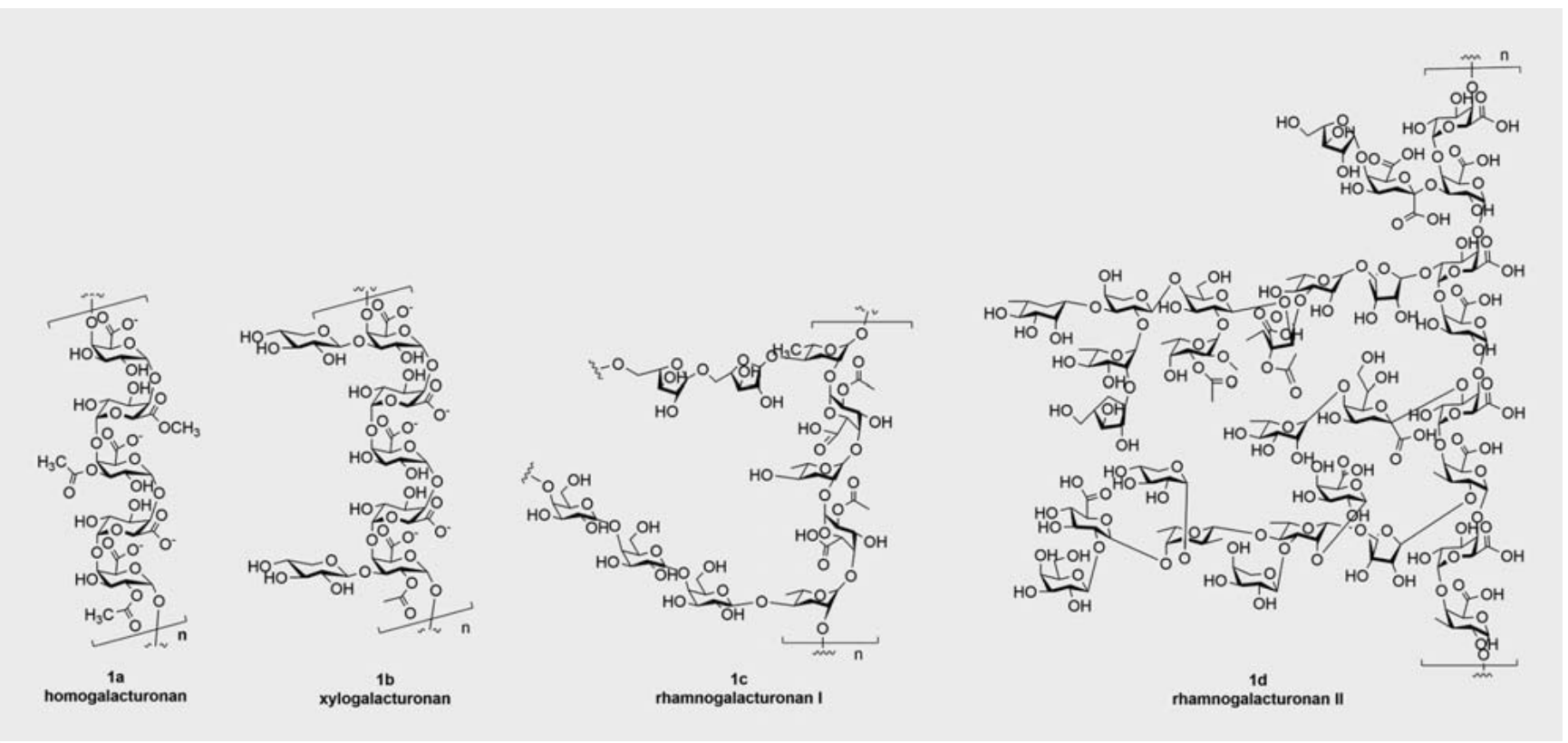

- Fig. 2 Structural elements of apple pectin. Homogalacturonan (1a), xylogalacturonan (1b), rhamnogalacturonan I (1c), and rhamnogalacturonan II (1d).

tion. Alcohol dehydrogenase and aspartate amino transferase are further involved in volatile compound formation. A rupture of the plant cell wall releases the enzyme lipoxygenase, leading to an increase in the formation of $C_{6}$ and $C_{8}$ aldehydes from linoleic and linolenic acid. Apple crushing, juice pressing and to a lower extent the normal ripening process alters the volatile pattern as different substrates are provided to the enzymatic system [29].

In dry apple pomace, Madrera and Valles [30] identified 48 esters, 30 aldehydes and ketones, 19 terpenes and norisoprenoids, nine acids, eight alcohols, four lactones, and six compounds of other chemical structure by stir-absorptive extraction followed by GC-MS analysis. The comparison of pomace volatile fractions from five cultivars revealed that the total number and the ratio of the constituents are variable. However, the main component of each chemical group was the same for all cultivars: benzaldehyde for the group of aldehydes and ketones; decanoic acid for the group of acids; a farnesol isomer for terpenes; and ethyldecanoate for the group of esters and lactones. The chemical group of alcohols represented an exception: in four of the five cultivars the main compound was 1-octen-3-ol, while in one cultivar it was 1-hexanol. In intact apples, the volatile compounds are embedded in the three-dimensional matrix of cutin ( $\triangleright$ Fig. 3 [2]). It consists of hardly dissolvable glycerol polyesters of hydroxylated or epoxy hydroxylated $\mathrm{C}_{16}$ and $\mathrm{C}_{18}$ fatty acids [31].

\section{Triterpenoids}

Triterpenoids are also located in the aforementioned layer of cutin. Ursolic ( $\triangleright$ Fig. 3 [3]) and oleanolic acid ( $\vee$ Fig. 3 [4]) are the main representatives but also numerous derivatives thereof (e.g., substituted with additional hydroxyl groups and $p$-coumaroyloxyor cinnamoyloxy-moities ( $\triangleright$ Fig. 3 [5]). In addition, their alcoholic derivatives have been isolated ( $\triangleright$ Fig.3 [6 and 7]) [32-36].
Although the number of structure-elucidated apple triterpenoids increases, their total quantity in apple pomace has hardly been investigated. Brieskorn and Klinger [33] reported that about $20 \%$ of the apple peel is extractable with petrol ether. The obtained extract contained $46 \%$ ursolic and oleanolic acid and at least another $24 \%$ of triterpenoic derivatives. Other authors postulated an extraction yield of pentacyclic triterpenoids from apple pomace of about $2 \%$ [37] or, more recently, of $7 \%$ by ultrasonic extraction with ethanol [38]. A quantification of 8 triterpenoic derivatives in frozen dried apple pomace resulted in a content of less than $0.01 \%$ [39]. These wide discrepancies are related to quantification and the different methods in use. Triterpenoic compounds only absorb around the wavelength of $200 \mathrm{~nm}$, by which various compounds also have minor absorption rates. Thus, group determinations by UV spectrophotometry are less selective. Quantification by HPLC-UV/DAD only brings selectivity if the individual peaks can be accurately separated from other matrix peaks and identified (e.g., by LC-MS/MS). However, due to the existence of various structural isomers, a proper separation and identification is difficult. Derivatization could be a strategy for quantification. However, the accuracy depends on the completeness of the derivatization step. Therefore, the available data should be regarded as an estimation of absolute quantities.

\section{Non-volatile acids}

The non-volatile acids malic, citric, and quinic acid mediate the sour to astringent taste of apples [40]. Predominantly, gene expression of a malic acid transporter mediating malic acid uptake into the plant cell vacuole seems to influence the malic acid concentration in apples and consequently their acidity value. During juice production, the major content is transferred to the juice, from which malic acid was isolated for the first time by Carl Wil- 

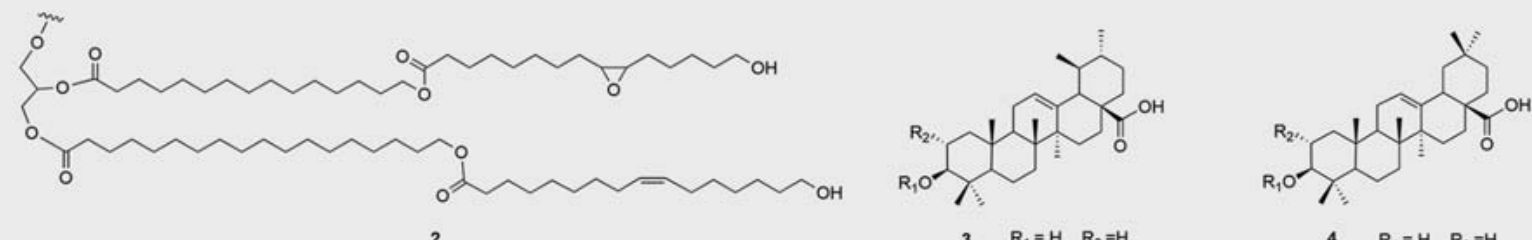

$3 \quad \mathrm{R}_{1}=\mathrm{H} \quad \mathrm{R}_{2}=\mathrm{H}$

$4 \quad R_{1}=H \quad R_{2}=H$
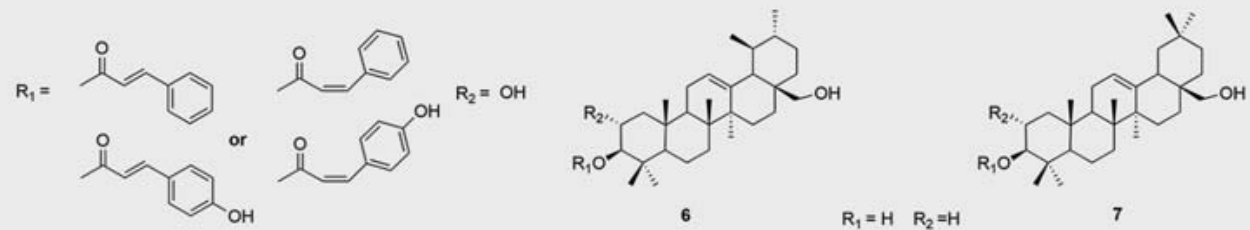

Fig. 3 Cutical constituents of apple present in apple pomace. Cutin (2), the triterpenoids ursolic acid (3), oleanolic acid (4), coumaroyl- and cinnamylderivatives of ursolic and oleanolic acid (5), uvaol (6), and erythrodiol (7).

helm Scheele in 1785 [41]. In apple pomace, an average amount of only $0.08 \%$ malic acid per absolute weight was detected in an investigation of 11 cultivars [26].

\section{Polyphenols}

Polyphenols, with the exception of lignin, are associated with the beneficial health effects mediated by fruits. Bitter-tasting cider apples, which are generally smaller and biennial, have higher total phenolic content than dessert apples, which are mainly used for direct consumption and juice production $[42,43]$.

By investigating 40 apple varieties, total phenolic contents between 66.2 and $211.9 \mathrm{mg} / 100 \mathrm{~g}$ were determined by the FolinCiocalteu method in fresh fruits. This demonstrates the wide range of polyphenolic content of different apple cultivars. The main compounds identified in the polyphenolic fraction were catechins and proanthocyanidins followed by hydroxycinnamates, flavonols, dihydrochalcones, and anthocyanins [43]. However, the number of single compounds varies up to $30 \%$ from one year to the other in the same cultivar [12].

Consequently, also in dry apple pomace, wide ranges of polyphenol contents were measured (e.g., 262 to $856 \mathrm{mg}$ of total phenols $/ 100 \mathrm{~g}$ or to a maximum concentration of only $350 \mathrm{mg} / 100 \mathrm{~g}$, respectively) $[16,44]$. The content of polyphenols per pomace weight increases compared to that per fresh fruit weight due to the water loss during pressing procedure. Polyphenols are partially transferred to the corresponding juices, but their predominant location is in the peel. Therefore, most polyphenols should remain in the pomace [45]. While all 13 compounds were detected in the peel, the recovery of some quercetin derivatives could neither be measured in the juice nor in the corresponding pomace indicating method deficiencies or degradation during manufacture. Other studies only measured the polyphenolic content of the apple juice and its pomace $[44,46]$. The concentration of apple polyphenols in the pomace seems to be influenced by the method of juice production [44]. The polyphenol concentration was higher in the pomace obtained from clear juice production. However, allover polyphenol recovery was higher in the apple pomace from cloudy juice production as it accrues higher pomace mass. This suggests the binding of polyphenols to pectin or other cell wall structures [47]. Pectinases used for clear juice production cleave these bindings and increase the number of polyphenols available for extraction.

Extensive studies on the identification of apple pomace polyphenols were conducted $[48,49]$. Detected compounds are listed in $>$ Table 1, and representatives from some structural classes are shown in > Fig. 4.

In fresh apple pomace, the polyphenolic pattern resembles that of fresh apples, showing high contents of chlorogenic acid ( Fig. 4 [13]), caffeic acid, (+)-catechin, (-)-epicatechin, rutin, and quercetin glycosides [50]. In contrast, phloridzin ( $\bullet$ Fig. 4 [8]) is the most prominent polyphenol in apple pomace after drying [51]. Phloridzin is absent in pomace obtained from other sources such as pears; thus, it is considered a good marker substance for dry apple pomace identification [52]. The method used for drying pomace has less impact on the content of polyphenols than the apple variety and the time to the onset of the drying process. Enzymes such as polyphenol oxidases and peroxidases are liberated from cell vacuoles or cell wall compartments during apple crushing and start the oxidation of o-diphenols to quinones, which then can condense with amino acid residues from proteins. These reactions are visible as a brown discoloration of the pomace after pressing [53]. Lavelli and Corti [8] revealed that phenolic compounds have highest stability in pomace samples with the lowest water activity. This supports the theory that enzymes mediate the degradation of polyphenols. Consequently, the most important step for polyphenol preservation in apple pomace is the immediate and effective drying process after pressing, which should inactivate the degrading enzymes. Gentle drying methods such as lyophilization additionally inhibit the formation of thermal degradation products such as 5-hydroxymethylfurfural from sugars [52].

\section{Ubiquitous components}

Macro- and microelements detected in apple pomace are sodium, potassium, calcium, phosphor and magnesium, iron, manganese, zinc, and copper with summed amounts of $0.79 \mathrm{~g} / 100 \mathrm{~g}$ and 
<smiles>O=C(CCc1ccc(O)cc1)c1c(O)cc(O)cc1OC1C(O)C(O)C(O)C(O)C1O</smiles><smiles>Oc1cc(O)c2c(c1)O[C@H](c1ccc(O)c(O)c1)[C@H](O)[C@H]2c1c(O)cc(O)c2c1C[C@H](O)[C@H](c1ccc(O)c(O)c1)C2</smiles>

9<smiles>O=c1cc(-c2ccc(O)c(O)c2)oc2cc(O)cc(O)c12</smiles>

10<smiles>O=C1C[C@H](c2ccc(O)cc2)Cc2cc(O)cc(O)c21</smiles>

11<smiles></smiles>

12

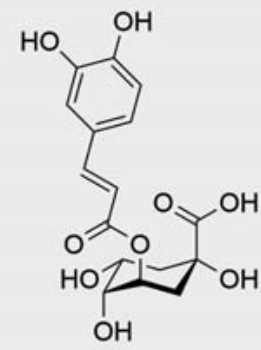

13

- Fig. 4 Polyphenols of apple pomace. Phloretin-2-O-glucoside (phloridzin) (8), procyanidin B2 (9), apigenin (10), naringenin (11), quercetin (12), and 3-O-caffeoylquinic acid (chlorogenic acid) (13).

$10.9 \mathrm{mg} / 100 \mathrm{~g}$, respectively [54]. A protein content of $0.002-$ $7.1 \%$ and an amino acid content of $2.3 \%$ were detected $[16,55]$. The ash content varies from 1.5 to $4.0 \%[13,16,54]$. Vitamin $E$ and vitamin C are present in amounts of 22.4 and $5.5 \mathrm{mg} / 100 \mathrm{~g}$, respectively $[54,56]$.

\section{Optimized extraction methods of selected apple pomace constituents}

A growing number of apple pomace publications focus on the optimization of compound extraction methods. They intend to increase extraction efficacy or to reduce ecological or economical disadvantages entailed by conventional extraction methods. This chapter gives an insight into this field of research.

\section{Pectin extraction}

The major part of the extracted pectin goes into the nutritional and cosmetic industry as a gelling or thickening agent. Highly standardized or chemically modified pectin is used for drug delivery systems $[57,58]$. Pectin can also be included in wound treatments due to its hemostatic effect [59]. Moreover, it showed potential to remove toxic heavy metals from human and animal biological systems [60].

The exploitation starts with a hot water-acid extraction, followed by the addition of ethanol to the up-concentrated extract, which leads to the precipitation of crude pectin. Acid treatments, filtrations, and washing steps lead to pectin with lower degrees of polymerization and esterification, which leads to high amounts of chemical waste. Therefore, alternative, environmentally friendly approaches of pectin extraction with high yields are of interest. Wang and Lu [61] used hot-compressed water extraction to replace the first extraction step performed with acids. The obtained pectin showed a lower viscosity rate, dry matter and protein content but higher ash and neutral sugar content.

Enzymatic extraction seems to be a more promising alternative. Commercially available enzyme preparations contain mixtures of cellulases and proteases. Under optimal conditions, enzymatic extraction delivers higher yields than acidic extraction [62]. They break down cell wall lamellae liberating the water-soluble pectin. Furthermore, the efficacy of pectin extraction was tested for single enzymes. For example, a polygalacturonase of Aspergillus kawachii, which was recombinantly won from Saccharomyces cerevisiae, showed 1.3-fold pectin extraction yield compared to chemical extraction. Yields of other commercially-available polygalacturonases were below the amounts reached by chemical extraction, but all enzymatically-extracted pectin had a higher degree of esterification [63]. Further studied enzymes are hemicellulase [64], xylanase and cellulase [65] with the yield ranking of xylanase $>$ hemicellulase $>$ cellulase. Although one would expect that the products combining several enzymes deliver higher extraction yields, xylanase reached the maximum result of about $19 \%$. The combination cellulase and xylanase decreased the pectin extraction yield [65].

To sum up, enzymatic pectin extraction depends on the individual enzyme activity. This may imply minor batch-to-batch variations of production yields, but it diminishes the use of strong acids and is able to produce pectin with favorable physical properties. Nevertheless, industrial application is limited by economic reasons, as extraction time increases up to six-fold.

Another way of optimizing pectin yield or quality is the modification of the precipitation step. While ethanol precipitates pectin 
- Table 1 Polyphenols identified in apple pomace $[48,49]$.

\begin{tabular}{|c|c|c|}
\hline Compound class & Compound name & $\begin{array}{l}\text { Number of not } \\
\text { identified isomers }\end{array}$ \\
\hline Dihydrochalcons & $\begin{array}{l}\text { phloretin, phloretin-2-O-glucoside, phloretin-2-O-xylosyl-glucoside, phloretin-pentosyl- } \\
\text { hexoside, phloretin-hexosyl-hexoside, 3-hydroxyphloretin-2'-O-xylosyl-glucoside, } \\
\text { 3-hydroxyphloretin-2'-O-glucoside }\end{array}$ & 2 \\
\hline \multirow[t]{2}{*}{ Flavanols } & $\begin{array}{l}\text { (+)-catechin, (-)-epicatechin, procyanidin B1, procyanidin B2, procyanidin B3, procyanidin } \\
\text { B5, procyanidin C1, ((epi)cat) trimer }\end{array}$ & 6 \\
\hline & ((epi)cat) tetramer & 7 \\
\hline Flavons & apigenin, chrysoeriol, luteolin, luteolin-7-O-galactoside, luteolin-7-O-glucoside & \\
\hline Flavanons & $\begin{array}{l}\text { eriodictyol, eriodictyol-hexoside, hesperidin-O-pentoside, naringenin, naringenin-7-O-glu- } \\
\text { coside, naringenin-7-O-neohesperidoside, naringenin-7-O-rutinoside, naringenin-O-glucu- } \\
\text { ronide, naringenin-O-hexoside }\end{array}$ & 4 \\
\hline \multirow[t]{2}{*}{ Flavonols } & $\begin{array}{l}\text { isorhamnetin-3-O-galactoside, isorhamnetin-3-O-glucoside, isorhamnetin-3-O-rutinoside, } \\
\text { isorhamnetin-3-O-arabinopyranoside, isorhamnetin-3-O-arabinofuranoside, isorhamnetin-3- } \\
\text { O-rhamnoside, kaempferol-O-glucoside, quercetin, quercetin 3-O-diglucoside }\end{array}$ & \\
\hline & $\begin{array}{l}\text { quercetin-3-O-arabinofuranoside, quercetin-3-O-arabinopyranoside, quercetin-3-O-galacto- } \\
\text { side, quercetin-3-O-glucoside, quercetin-3-O-rhamnoside, quercetin-3-O-rutinoside querce- } \\
\text { tin-3-O-xylanoside, quercetin- } O \text {-hexoside, quercetin- } O \text {-pentosyl-hexoside, quercetin- } O \text {-pen- } \\
\text { toside, quercetin- } O \text {-xylosyl-pentoside, rhamnetin, rhamnetin-3-O-glucoside }\end{array}$ & \\
\hline \multirow[t]{4}{*}{ Hydroxycinnamic acids } & caffeic acid-O-hexoside & 2 \\
\hline & $\begin{array}{l}\text { 3-O-caffeoylquinic acid, 4-O-caffeoylquinic acid, 5-O-caffeoylquinic acid, x-O-caffeoylquinic } \\
\text { acid, dicaffeoylquinic acid }\end{array}$ & 8 \\
\hline & ferulic acid-O-hexoside & 2 \\
\hline & $\begin{array}{l}\text { p-coumaric acid- } O \text {-hexoside, 4-O-p-coumaroylquinic acid, 5-O-p-coumaroylquinic acid, } \\
\text { p-coumaroylquinic acid, sinapic acid- } O \text {-glucoside }\end{array}$ & 3 \\
\hline Anthocyanins & cyanidin-3-O-galactoside, cyanidin-3-O-hexoside & \\
\hline Other & protocatechuic acid, salicylic acid & \\
\hline
\end{tabular}

quantitatively, but not selectively, sodium caseinate targets charged pectin of high molecular weight [66]. However, ethanol precipitation is still regarded as state of the art.

\section{Microcrystalline cellulose}

Microcrystalline cellulose is used as an excipient in the pharmaceutical and food industry. Guo and Luo [67] reported the optimum conditions for the isolation of microcrystalline cellulose from apple pomace: $6 \%$ hydrochloric acid, a solid-liquid ratio of 25 , and a concentration of $2.5 \mathrm{~mL}$ sodium hypochlorite per $100 \mathrm{~mL}$ extraction mixture.

\section{Dietary fiber}

Instead of isolating a specific fiber type from apple pomace, the native apple pomace or the residue from pectin extraction, the so-called apple pomace fiber, can be used. It can be directly added to dietary products to modify the fiber content or the physical properties.

Ultra-fine pulverization of dry apple pomace fiber influences its physical properties, such as water solubility, swelling capacity, and product lightness, as well as its pharmacological effects such as cholesterol adsorption, which enhances, while fatty acid and bile acid absorption, water binding capacity, and cation exchange capacity lowers $[68,69]$. Furthermore, the effect on dietary fibers by bleaching $\left(\mathrm{H}_{2} \mathrm{O}_{2}\right.$-alkaline process) and desugaring (water ex- traction at room temperature) was investigated [69]. Bleaching resulted in yellow cellulose-rich fiber concentrates with increased water-holding and swelling capacity. The same changes were observed for the desugared pomace.

\section{Polyphenols}

The extraction of polyphenols is a highly investigated field due to their low concentration in pomace. Sophisticated methods are needed to provide sufficient extraction yields.

The first factor to influence the extractable number of polyphenols is the drying process. Vacuum drying is generally regarded as a better alternative to oven drying as it preserves higher polyphenol contents [6]. However, this is not the case for anthocyanins and flavanols [8]. It seems that the drying efficacy has a higher impact on polyphenol stability than the drying method.

Polyphenol recovery further depends on the extraction solvent and the extraction technique. Investigations of the latter, in particular, lead to controversial results in the literature. $~ T a b l e ~ 2$ lists extraction yields obtained with different extraction techniques on the basis of total phenolic contents in milligrams per 100 grams of pomace weight, determined by the Folin-Ciocalteu method.

Independently from the extraction technique, organic water mixtures provide extraction yields superior to pure water. However, when high amounts of raw material are intended for extraction, the latter should be preferred for environmental reasons. An 
- Table 2 Extraction techniques for polyphenols from apple pomace.

\begin{tabular}{|c|c|c|c|}
\hline Technique & Optimized condition & Total phenolic content (dry weight) ${ }^{1}$ & Reference \\
\hline \multirow[t]{2}{*}{ Stirring } & $\begin{array}{l}\text { acetone } 65 \%, 60 \mathrm{~min}, 25^{\circ} \mathrm{C} \\
\text { solid/liquid ratio }(\mathrm{g} / \mathrm{mL}): 1: 100\end{array}$ & $1415 \mathrm{mg}$ GAE $/ 100 \mathrm{~g}$ & [141] \\
\hline & $\begin{array}{l}\text { water, } 37 \mathrm{~min}, 100^{\circ} \mathrm{C} \\
\text { solid/liquid ratio }(\mathrm{g} / \mathrm{mL}): 1: 100\end{array}$ & $834.1 \mathrm{mg} \mathrm{GAE} / 100 \mathrm{~g}$ & [142] \\
\hline Shaking & $\begin{array}{l}\text { water, } 30 \mathrm{~min}, 85^{\circ} \mathrm{C} \\
\text { solid/liquid ratio }(\mathrm{g} / \mathrm{mL}): 1: 20\end{array}$ & $118.6 \mathrm{mg} \mathrm{GAE} / 100 \mathrm{~g}$ & [143] \\
\hline \multirow[t]{3}{*}{ Ultrasound } & $\begin{array}{l}\text { ethanol, } 10 \mathrm{~min}, 65^{\circ} \mathrm{C}, 503 \mathrm{~W} \\
\text { solid/liquid ratio }(\mathrm{g} / \mathrm{mL}): 1: 30\end{array}$ & $453 \mathrm{mg} / 100 \mathrm{~g}$ & [144] \\
\hline & $\begin{array}{l}\text { water, } 40^{\circ} \mathrm{C}, 0.764 \mathrm{~W} / \mathrm{cm}^{2} \\
\text { solid/liquid ratio }(\mathrm{g} / \mathrm{mL}): 1: 6.7\end{array}$ & $551.7 \mathrm{mg} C A E / 100 \mathrm{~g}$ & [145] \\
\hline & $\begin{array}{l}\text { ethanol } 50 \%, 45 \mathrm{~min}, 40.1^{\circ} \mathrm{C}, 0.142 \mathrm{~W} / \mathrm{g} \\
\text { solid/liquid ratio }(\mathrm{g} / \mathrm{mL}): 1: 6.7\end{array}$ & $971.3 \mathrm{mg}$ CAE $/ 100 \mathrm{~g}$ & [146] \\
\hline \multirow[t]{2}{*}{ Microwave } & $\begin{array}{l}\text { ethanol } 62.1 \%, 53.7 \mathrm{~s}, 650.4 \mathrm{~W} \\
\text { solid/liquid ratio }(\mathrm{g} / \mathrm{mL}): 1: 22.9\end{array}$ & $62.7 \mathrm{mg}$ GAE $/ 100 \mathrm{~g}$ & [147] \\
\hline & $\begin{array}{l}\text { ethanol } 60 \%, 149 \mathrm{~s}, 735 \mathrm{~W} \\
\text { solid/liquid ratio }(\mathrm{g} / \mathrm{mL}): 1: 10.3\end{array}$ & $1580 \mathrm{mg}$ GAE $/ 100 \mathrm{~g}$ & [148] \\
\hline Subcritical fluid extraction & $\begin{array}{l}\mathrm{CO}_{2} \text { + ethanol } 20 \%, 40 \mathrm{~min}, 54.6-57 \mathrm{MPa} \text {, } \\
55.7-58.4^{\circ} \mathrm{C} \\
\text { solid/liquid ratio }(\mathrm{g} / \mathrm{mL}): 1: 3\end{array}$ & $47 \mathrm{mg} \mathrm{GAE} / 100 \mathrm{~g}$ & [149] \\
\hline
\end{tabular}

alternative approach to increase the polyphenol yield from apple pomace is fermentation with Phanerochaete chrysosporium. This fungus emits ligninolytic enzymes and $\beta$-glucosidase, liberating polyphenols bound to cell wall structures and increasing the extractable number of polyphenols [70]. Comparable to the use of pectinases during the production of clear apple juice, the addition of isolated enzymes such as cellulase leads to an increase in extractable polyphenols from apple pomace [71]. Polyphenols can also be gained by the use of $\beta$-cyclodextrin solutions [72] or resins [73] added to apple pomace slurries. Via a combination of empirical and statistical analysis, optimized conditions can be determined for every extraction technique. Based on the available literature, none of the presented techniques could be identified as superior. On an industrial scale, the selection of the extraction method depends on the amount of material intended for extraction.

\section{Biological activities}

Ethnopharmacological studies indicate the usage of apple against several ailments. Teas or decocts containing dried apple fruits or apple peels have been used as antitussives [74,75]. Apple vinegar intake was intended to "clean the kidneys" and to treat indigestion and arthritis. The vinegar has also been used externally against burn, wasp stings, and headache. The fresh fruit has been consumed for the treatment of constipation [76].

More recently, epidemiological and intervention studies emphasize that apple consumption leads to beneficial health effects $[77,78]$, while those of apple juice consumption are controversially discussed $[79,80]$. This leads to the assumption that the pomace could contain especially those apple constituents that mediate the beneficial health effects. This section summarizes the health-promoting properties of apple pomace and its constituents.

\section{Digestion and metabolism}

Back when farmers used to produce small amounts of apple juice from their own orchards, the pomace was commonly fed to the animals on the farm in addition to their normal diets. With the increasing livestock of fattening animals, apple pomace soon became an inferior feed due to its low protein content, although the up-scale to industrial production of apple juice provides tons of low-price apple pomace every year. Consequently, it has been mainly fed to deer held in hunting reserves. Following the aforementioned hypothesis that the consumption of apple residues may mediate beneficial health effects, research efforts have been expanding to the topic of human consumption of apple pomace.

Several animal and human intervention studies measured a decreased $\mathrm{pH}$ of cecel and colonic digesta and the feces after the ingestion of native apple pomace and preparations thereof. This is the result of an enhanced production of short-chain fatty acids from the gut microbiome during apple pomace consumption $[55,79,81-83]$. Ethanol-extracted and native apple pomace decreased the intestinal $\mathrm{pH}$ [55]. The fiber content seems to be mainly responsible for the effect. Fibers could act as prebiotics favoring the growth of saccharolytic bacteria and resulting in an adaptation of the microflora to the new substrate availability during the apple pomace diet. Indeed, this was measured in feces samples of weaning pigs. A supplementation of the control diet with $3.5 \%$ of apple pomace lead to enhanced rates of Lactobacilli, while Streptococci and Enterococci numbers were tentatively reduced [84]. 
Concurrently, the relative proportions of fatty acid composition changes during apple pomace diet. In Wistar rats the number of intestinal branched-chain fatty acids decreases, while the number of total short-chain fatty acids increases (except propionic and valeric acid) [55]. Other studies also postulated the increase of acetic, propionic, and butyric acid content during apple pomace diet $[85,86]$. The consumption of apple pomace with reduced polyphenol content led to the most effective reduction of intestinal isobutyric acid and isovaleric acid concentration [85].

A human comprehensive cross-over study with a treatment duration of four weeks tested the intake of either whole apples, clear or cloudy apple juice, or $22 \mathrm{~g}$ of apple pomace per day. The study revealed lower intestinal amounts of 3-hydroxybutyric acid, 2-hydroxy-3-methylbutyric acid, and $\alpha$-ketoisovaleric acid [87]. Recently, isobutyric and isovaleric acid were associated with a reduction of cyclic adenosine monophosphate (cAMP)-mediated lipolysis and insulin-stimulated de novo lipogenesis, as well as the potential to increase insulin-dependent glucose uptake [88].The reduction of branched short-chain fatty acids could be interpreted as a negative effect of apple pomace consumption. However, the same study emphasized the higher potential of non-branched short-chain fatty acids to mediate these aforementioned effects.

Propionic and butyric acid are associated with the prevention of metabolic syndrome and diabetes, and high intestinal concentrations are inversely correlated to inflammatory bowel disease $[89,90]$. The influenced physiological mechanisms could be multivariant. First, when absorbed by colonocytes, they serve as an energy source stimulating mucosa production, which results in an improved gut barrier function against pathogens. They play a role in gut bacterial cross-feeding mechanisms, PPARy downregulation, differentiation of T-cells, and gut hormone concentration regulating the appetite [89].

Dietary fibers, pectin in particular, seem to increase the nonbranched short-chain fatty acid concentration in the gut. However, an impact of polyphenols that are embedded or bound to dietary fibers can also be hypothesized $[55,85,86]$.

A further indicator of the nutritional influence from apple pomace on the bacterial milieu of the intestine is the detection of bacterial enzymes in the cecel digesta. Two studies investigated the effect of apple pomace diet on the level of intestinal $\alpha$ - and $\beta$ glucosidases, $\alpha$ - and $\beta$-galactosidases, and $\beta$-glucuronidase in Wistar rats. While one study reported moderate increases of $\alpha$ and $\beta$-glucosidases, as well as $\alpha$ - and $\beta$-galactosidases [85], a decrease of bacterial $\beta$-glucosidase activity and no significant effects on the other enzymes were observed by the other study [55]. $\beta$ glucuronidase was significantly decreased in all apple pomace intervention groups of both studies. This is associated with a reduced risk of colon carcinogenesis [91]. However, the extrapolation of these results from rat studies to the human body must be considered carefully, and further studies investigating the effects on the human microbiome activity should be performed.

Another observation during apple pomace intervention in rats was the increase of cecel $\mathrm{N}$-excretion $[55,81]$. This occurred together with a decrease in urinary $\mathrm{N}$-excretion and a tentative reduction of ammonia content in feces, which could be associated with a repression of proteolytic bacteria growth during apple pomace diet. The hypothesis is reinforced by the aforementioned measured decrease of intestinal branched short-chain amino acid concentrations, which are metabolites of aromatic and branchedchain amino acids.

Furthermore, lowered rates of medium- and short-chain acylcarnitines, the storage forms of L-carnitine, which is de novo synthesized from the amino acids lysine and methionine, were measured [87]. The effect was significant during consumption of whole apples and apple pomace, but not for apple juices. Therefore, apple dietary fibers or pectin could be associated with the effect.

Ingestion of apple pomace influences not only bacterial colonization and bacterial enzymes but also the mucosal activity itself. For example, maltase and sucrase activity were lowered under apple pomace consumption [81]. In vitro, it could be demonstrated that pectin, isolated from apple pomace via citric acid or hydrochloric acid extraction, is a competitive inhibitor of the pancreatic lipase [92]. The resulting lipase-pectin complex degrades after approximately $30 \mathrm{~min}$. While the administration of a pectin-lipase ratio of 2:1 did not prolong the effect, physicochemical properties make up a difference. The lipase-pectin complex formed with pectin isolated by citric acid extraction was more stable.

A positive side effect of apple pomace ingestion is the waterbinding activity of apple fibers resulting in an enhanced cecel mass under unvarying or even smaller dry mass. This could be beneficial for peristaltic effects, and therefore, the apple pomace is tested not only for human nutrition and the feed of herbivorous animals, but also as an addition to, for example, dog feed [83]. Grinded stale apple slices have been traditionally used to treat diarrhea, especially in children. Preparations containing apple pectin and a chamomile extract showed clinical efficacy for the treatment of diarrhea in children [93]. The pharmacological mechanism may involve bacterial toxin adsorption by pectin and the aforementioned effects on gut microbiome and intestinal mucosal activity.

\section{Cholesterol and triglycerides homeostasis}

The most evident effect mediated by the consumption of apple pomace or preparations thereof is on cholesterol and triglyceride homeostasis.

Despite the existence of studies reporting a negative effect on serum total and HDL cholesterol level after apple pomace intake [81], studies postulating a positive effect prevail ( $\vee$ Table 3 ).

These positive effects are mainly associated with the soluble dietary fiber content of the pomace $[94,95]$. The mechanism of action may be an increase of cholesterol excretion and an inhibition of gastrointestinal reabsorption of primary bile acids [87]. This promotes cholesterol uptake, synthesis, and turnover in the liver, leading to a decrease of cholesterol serum levels [96]. The molecular mechanism behind the reduction of serum triglyceride levels may be explained via the aforementioned inhibition of the lipoprotein lipase [92].

Growing evidence indicates that also the apple pomace polyphenols contribute to the positive effects [97]. The combination of apple pectin and a polyphenol-rich apple concentrate significantly decreased plasma cholesterol and triglyceride levels, as well as intestinal cholesterol absorption. Furthermore, liver cholesterol storage level lowered more significantly under the combined diet 
- Table 3 Rat studies investigating the effect of apple pomace intake on cholesterol- and triglyceride level.

\begin{tabular}{|c|c|c|c|c|}
\hline Test model & Test regime & & $\begin{array}{l}\text { Effects on serum concentration or indicated } \\
\text { biological activities (significance) }\end{array}$ & Reference \\
\hline $\begin{array}{l}\text { Sprague } \\
\text { Dawley rat (8) }\end{array}$ & $\begin{array}{l}10 \text { days } \\
\text { Control (CP): } 1 \% \text { cholesterol and } 0.25 \% \text { sodium cholate, } \\
5 \% \text { cellulose; apple pomace powder (AP): } 1 \% \text { cholesterol } \\
\text { and } 0.25 \% \text { sodium cholate, } 5 \% \text { apple pomace powder; } \\
\text { insoluble dietary fiber (IDF): } 1 \% \text { cholesterol and } 0.25 \% \\
\text { sodium cholate, } 3.73 \% \text { insoluble dietary fiber from apple } \\
\text { pomace; soluble dietary fiber (SDF): } 1 \% \text { cholesterol and } \\
0.25 \% \text { sodium cholate, } 1.27 \% \text { soluble dietary fiber from } \\
\text { apple pomace }\end{array}$ & SDF & $\begin{array}{l}\downarrow \text { total cholesterol concentration }(p<0.05 \text { vs. CP) } \\
\downarrow \text { liver cholesterol concentration }(p<0.05 \text { vs. IDF) }\end{array}$ & [94] \\
\hline Wistar rat (60) & $\begin{array}{l}40 \text { days } \\
\text { Control: basal diet; Cholesterol (Chol): basal diet }+3 \mathrm{~g} / \mathrm{kg} \\
\text { cholesterol; Apple pomace fiber (AP): basal diet }+100 \mathrm{~g} / \\
\mathrm{kg} \text { apple pomace fiber; Apple pomace fiber + cholesterol } \\
(\mathrm{AP}+\mathrm{Chol}) \text { : basal diet }+100 \mathrm{~g} / \mathrm{kg} \text { apple pomace fiber+ } \\
3 \mathrm{~g} / \mathrm{kg} \text { cholesterol }\end{array}$ & $\begin{array}{l}\mathrm{AP}+ \\
\text { Chol }\end{array}$ & $\begin{array}{l}\downarrow \text { total cholesterol concentration ( } p<0.05 \text { vs. Chol) } \\
\downarrow \text { LDL-cholesterol concentration ( } p<0.05 \text { vs. Chol) } \\
\downarrow \text { triglyceride concentration ( } p<0.05 \text { vs. Chol) } \\
\downarrow \text { total phospholipid concentration ( } p<0.01 \text { vs. Chol) } \\
\uparrow \text { HDL-phospholipid concentration ( }<<0.05 \text { vs. Chol) } \\
\downarrow \text { liver total cholesterol concentration ( }<<0.0005 \text { vs. } \\
\text { Chol) }\end{array}$ & [95] \\
\hline $\begin{array}{l}\text { Wistar rats } \\
\text { (male, } 10)\end{array}$ & $\begin{array}{l}21 \text { days } \\
\text { Control: basal diet; Apple pectin (PEC): basal diet + 5\% } \\
\text { apple pectin; Apple (cider) (PL): basal diet }+10 \% \text { apple } \\
\text { (cider, rich in catechin, epicatechin, procyanidins, } \\
\text { chlorogenic acid, coumaroylquinic acid and phloridzin); } \\
\text { Mixed (PEC+PL): basal diet }+5 \% \text { apple pectin }+10 \% \text { apple } \\
\text { (cider) }\end{array}$ & $\begin{array}{l}\text { PEC } \\
P L \\
P E C+P L\end{array}$ & $\begin{array}{l}\uparrow \text { portal vein bile acids ( } p<0.05 \text { vs. control) } \\
\downarrow \text { fecal bile acid excretion ( } p<0.05 \text { vs. control) } \\
\uparrow \text { fecal cholesterol, coprostanol, total steroid excretion } \\
\text { ( } p<0.05 \text { vs. control or trend) } \\
\downarrow \text { cholesterol absorption (trend) } \\
\uparrow \text { body weight gain ( } p<0.05 \text { vs. control) } \\
\downarrow \text { plasma triglyceride concentration ( } p<0.05 \text { vs. } \\
\text { control) } \\
\downarrow \text { body weight gain ( }<<0.05 \text { vs. control) } \\
\uparrow \text { portal vein bile acids (trend) } \\
\downarrow \text { fecal bile acid excretion ( }<<0.05 \text { vs. control) } \\
\uparrow \text { fecal cholesterol, coprostanol, steroid excretion } \\
\text { ( } p<0.05 \text { vs. control or trend) } \\
\downarrow \text { cholesterol absorption (trend) } \\
\downarrow \text { plasma cholesterol and triglyceride concentration } \\
\text { ( } p<0.05 \text { vs. control) }\end{array}$ & [97] \\
\hline $\begin{array}{l}\text { Wistar rats } \\
\text { (male, } 48 \text { ) }\end{array}$ & $\begin{array}{l}4 \text { weeks } \\
\text { Control: basal diet + water; } \\
\text { Intervention group (IV): basal diet + apple pomace } \\
\text { extraction juice }\end{array}$ & IV & $\begin{array}{l}\downarrow \text { food intake after } 2 \text { weeks ( } p<0.05 \text { vs. control) } \\
\uparrow \text { liquid intake after } 2 \text { and } 4 \text { weeks ( } p<0.001 \text { vs. } \\
\text { control) } \\
\uparrow \text { urine excretion after } 2 \text { weeks ( } p<0.05 \text { vs. control) } \\
\uparrow \text { urine excretion after } 4 \text { weeks ( } p<0.001 \text { vs. control) } \\
\uparrow \text { cecel, colonic, and fecal concentration of primary } \\
\text { and total bile acids ( } p<0.001 \text { vs. control) } \\
\downarrow \text { cecel, colonic, and fecal concentration of secondary } \\
\text { bile acids ( } p<0.001 \text { vs. control) } \\
\uparrow \text { (cecal) and fecal cholesterol, coprostanol, coprosta- } \\
\text { non, and (cholestanon) concentration ( } p<0.001 \text { vs. } \\
\text { control or trend) }\end{array}$ & [98] \\
\hline $\begin{array}{l}\text { Wistar rats } \\
\text { (male, } 32 \text { ) }\end{array}$ & $\begin{array}{l}4 \text { weeks } \\
\text { basal diet + cellulose (control) basal diet + natural apple } \\
\text { pomace (AP); basal diet + ethanol-extracted apple } \\
\text { pomace (containing } 0.10 \% \text { polyphenols) (APE); basal } \\
\text { diet + ethanol and acetone extracted apple pomace } \\
\text { (containing } 0.01 \% \text { polyphenols) (APA) }\end{array}$ & APE & $\begin{array}{l}\downarrow \text { triglyceride concentration ( } p<0.05 \text { vs. control or } \\
\text { trend) } \\
\downarrow \text { total cholesterol concentration ( } p<0.05 \text { vs. control } \\
\text { or trend) } \\
\uparrow \mathrm{HDL} \% \text { of total cholesterol ( } p<0.05 \text { vs. control or } \\
\text { trend) } \\
\downarrow \text { LDL-cholesterol concentration ( } n s) \\
\downarrow \text { log (triglycerides/HDL cholesterol) ( } p<0.05 \text { vs. } \\
\text { control or trend) } \\
\uparrow \text { triglyceride concentration ( } p<0.05 \text { vs. AP, APA) } \\
\uparrow \text { total cholesterol concentration ( } p<0.05 \text { vs. AP, APA) } \\
\uparrow \text { log (triglycerides/HDL cholesterol) }(p<0.05 \text { vs. AP) } \\
\uparrow \mathrm{HDL} \% \text { of total cholesterol ( } p<0.05 \text { vs. AP, APE) } \\
\uparrow \log \text { (triglycerides/HDL cholesterol) ( } p<0.05 \text { vs. AP) }\end{array}$ & [85] \\
\hline
\end{tabular}


- Table 3 Continued

\begin{tabular}{|c|c|c|c|c|}
\hline Test model & Test regime & & $\begin{array}{l}\text { Effects on serum concentration or indicated } \\
\text { biological activities (significance) }\end{array}$ & Reference \\
\hline $\begin{array}{l}\text { Sprague- } \\
\text { Dawley rats } \\
(32)\end{array}$ & $\begin{array}{l}5 \text { weeks } \\
\text { Negative control: normal diet (ND); } \\
\text { Positive control: high fat diet (HFD); } \\
\text { Apple pomace intervention: } \mathrm{HFD}+10 \% \text { apple pomace } \\
\text { (AP) Apple juice concentrate intervention: } \\
\text { HFD }+10 \% \text { apple juice concentrate (AC) }\end{array}$ & AP & $\begin{array}{l}\downarrow \text { weight gain ( } p<0.05 \text { vs. ND and HFD) } \\
\downarrow \text { food intake }(p<0.05 \text { vs. ND) } \\
\downarrow \text { total cholesterol concentration ( } p<0.05 \text { vs. HFD) } \\
\uparrow \text { HDL cholesterol concentration ( } p<0.05 \text { vs. ND and } \\
\text { HFD) } \\
\downarrow \text { LDL cholesterol concentration ( } p<0.05 \text { vs. HFD) } \\
\downarrow \text { triglyceride concentration ( } p<0.05 \text { vs. ND and HFD) } \\
\downarrow \text { liver total cholesterol concentration ( } p<0.05 \text { vs. } \\
\text { HFD) } \\
\downarrow \text { liver triglyceride concentration ( } p<0.05 \text { vs. HFD) } \\
\downarrow \text { weight gain ( } p<0.05 \text { vs. HFD) } \\
\downarrow \text { food intake }(p<0.05 \text { vs. ND) } \\
\downarrow \text { total cholesterol concentration ( } p<0.05 \text { vs. HFD) } \\
\uparrow \text { HDL cholesterol concentration ( } p<0.05 \text { vs. HFD) } \\
\downarrow \text { LDL cholesterol concentration }(p<0.05 \text { vs. HFD) } \\
\downarrow \text { triglyceride concentration ( } p<0.05 \text { vs. ND and HFD) } \\
\downarrow \text { liver total cholesterol concentration ( } p<0.05 \text { vs. } \\
\text { HFD) } \\
\downarrow \text { liver triglyceride concentration ( } p<0.05 \text { vs. HFD) }\end{array}$ & [15] \\
\hline $\begin{array}{l}\text { Wistar rats } \\
\text { (male, 20) }\end{array}$ & $\begin{array}{l}2 \text { weeks } \\
\text { Semi-purified casein diet + cellulose fiber + maize starch } \\
\text { (control); Apple fiber preparation: semi-purified casein } \\
\text { diet }+6.7 \% \text { dried apple pomace without seeds (AFP) }\end{array}$ & AFP & $\begin{array}{l}\uparrow \text { total cholesterol (trend) } \\
\downarrow \text { HDL cholesterol (trend) } \\
\downarrow \text { HDL/total cholesterol ratio ( } p<0.05 \text { vs. control) }\end{array}$ & [81] \\
\hline $\begin{array}{l}\text { Wistar rats } \\
\text { (male, 32) }\end{array}$ & $\begin{array}{l}34 \text { days } \\
\text { Control: basal diet }+50 \mathrm{~g} / \mathrm{kg} \text { cellulose } \\
\text { apple pomace (AP): basal diet }+69 \mathrm{~g} / \mathrm{kg} \text { apple pomace }\end{array}$ & AP & $\begin{array}{l}\downarrow \text { triglyceride concentration ( } p<0.05 \text { vs. control) } \\
\downarrow \text { total cholesterol concentration ( } n s) \\
\downarrow \text { liver cholesterol concentration }(p<0.05 \text { vs. control) } \\
\downarrow \text { liver fat (ns) }\end{array}$ & [150] \\
\hline
\end{tabular}

than under single apple dietary fiber diet. The reduction of serum triglycerides was significant only in the group receiving the polyphenol-rich apple preparation in this study. This indicates that soluble dietary fibers seem not to mediate the positive effects on cholesterol homeostasis alone and that polyphenols may have a major impact on the reduction of plasma triglyceride concentration.

A fiber- and polyphenol rich preparation from apple pomace, namely a juice obtained by the use of pectinases and cellulases, increased cecel and fecal neutral sterol and primary bile acid excretion [98]. Intervention groups in a rat study, receiving either native apple pomace, ethanol-, or ethanol-and acetone-extracted apple pomace showed significantly reduced blood levels of triglycerides and total cholesterol. The HDL proportion increased compared to a control diet group with cellulose as single fiber source. Most effective on triglycerides and total cholesterol level was the natural pomace diet, offering both soluble dietary fibers and polyphenols [85].

Sprague-Dawley rats under high fat diet either supplemented by $10 \%$ apple pomace or $10 \%$ apple juice concentrate showed decreased levels of blood triglyceride levels and an enhanced HDL cholesterol concentration. Additionally, body weight gain, white adipose tissue proportion, subcutaneous and epidermal adipocyte size, as well as subcutaneous fat pads size was smaller. All effects were more evident in the groups supplemented with apple pomace than in the apple juice concentrate group, which again in- dicates that a combination of dietary fibers and other secondary metabolites may have additive or synergistic effects [15].

Forty male NIH mice were divided into a control group and four hyperlipidemia groups induced by intravenous injection of Triton WR-1339. Three of the intervention groups were additionally treated with fenofibrate, $200 \mathrm{mg}$ or $400 \mathrm{mg}$ of an apple pomace polyphenol extract per $10 \mathrm{~g}$ body weight for 7 days. In all treatment groups, serum triglyceride concentrations were lower. As in this study hyperlipidemia was induced by intravenous application, the protective effect mediated by apple pomace polyphenols cannot be based on an inhibition of triglyceride resorption. Indeed, the authors measured enhanced serum lipoprotein lipase activity, hepatic triglyceride lipase activity, and hepatic PPAR $\alpha$ mRNA level [99].

Current evidence is predominantly based on animal studies. In healthy human volunteers, effects were shown on plasma total and LDL cholesterol concentrations for a daily dose of $22 \mathrm{~g}$ of apple pomace, $550 \mathrm{~g}$ of whole apples, and $500 \mathrm{~mL}$ of cloudy apple juice, but not for $500 \mathrm{~mL}$ of clear apple juice [79]. Here as well, apple pomace showed the highest significance. Thus, it can be hypothesized that the limiting parameter for additive or synergistic effects of soluble dietary fibers and polyphenols is the polyphenol content. In pomace, polyphenol concentration per gram is higher than that in the same weight of whole apple due to the water loss.

However, one must consider the bioavailability as the limitation of their physiological effects. Decreased serum triglyceride level, total, LDL, and especially oxidized LDL cholesterol concen- 
trations of a Portuguese apple cultivar has been associated with the apple polyphenols (-)-epicatechin, $(+)$-catechin, procyanidin $\mathrm{B} 1$, and $\beta$-carotene [100]. Good gastrointestinal bioavailability of procyanidins and their ability to bind HDL cholesterol was reported for in vitro digestion [101].

Indirectly, livestock animals under apple pomace diet could have beneficial effects on human blood cholesterol levels. Broiler chickens under apple pomace diet had significantly lower meat cholesterol as well as thiobarbituric acid reactive substances content [102].

\section{Cardiovascular effects}

Effects of apple pomace consumption on cardiovascular health have hardly been investigated. Long-term apple consumption has been associated with a reduction of coronary mortality [103], but instant effects on blood pressure by apple consumption are controversially discussed [104, 105]. An apple peel extract and the majority of its constituents, predominantly flavonoids and especially some quercetin derivatives, inhibited the angiotensin converting enzyme activity in vitro [106]. In a previous study, we demonstrated that a mixture isolated from apple pomace containing various triterpenoic acids and quercetin is able to enhance the activity of the endothelial nitric oxide synthase in EA.hy926 cells [36]. Both of these molecular mechanisms are associated with vasodilation effects and, therefore, could be physiologically relevant.

\section{Diabetes}

Apple (pomace) consumption may counteract disorders in glucose metabolism at an early stage. It has been shown that after four weeks of daily apple or apple preparation intake the plasma concentration of 3-carboxy-4-methyl-5-propyl-2-furanopropanoic acid (CMPF) declines [87]. Risen CMPF plasma levels have been measured in patients with gestational or type-2 diabetes and impaired glucose-tolerant patients, indicating that CMPF is a sensitive marker for disorders in glucose metabolism [107].

In an open-label, randomized cross-over study, six female test persons underwent an oral glucose tolerance test with and without the additional intake of $25 \mathrm{~g}$ apple pomace preparation [108]. The preparation from blanched unripe apples was served in powdered form. The maximum blood glucose concentration was on average two-fold lower in the apple pomace preparation intaking group. Concurrently, the urinary excretion of glucose increased 20 -fold during the first $2 \mathrm{~h}$ after glucose intake and was still elevated five-fold after $2-4 \mathrm{~h}$. Phloridzin and its metabolites phloridzin-2'-O-glucuronide, phloretin-O-glucuronide, and phloretin were detected in urine. The whole study was designed to achieve high intake concentrations of phloridzin which is a well-known specific inhibitor of intestinal and renal glucose uptake [109]. The elucidated molecular mechanism of this effect is the competitive inhibition of sodium-linked glucose transporter (SLGT) 1 and 2 , of which SLGT-1 is predominantly located in the small intestine and SLGT-2 on the apical domain of the proximal convoluted renal tubule [110]. Due to this non-selective effect, isolated phloridzin could not be used as an antidiabetic drug, as it causes severe gastrointestinal side effects. Additionally, rapid deglycosidation by intestinal glycosidases lowers its oral bioavailability. In 2012, the first selective SLGT-2 inhibitor, dapagliflozin, was registered in the European Union, which is structurally based on phloridzin. This led to a new class of antidiabetic drugs: the gliflozins [111].

Another potential target of phloridzin might be the mitogenactivated protein kinase 1 (MAPK1), according to computational studies [112].

Quercetin could also exhibit antidiabetic properties, especially in early-stage type-2 diabetes. Intraperitoneal injection of quercetin prevented pancreatic $\beta$-cells from damage caused by streptozotocin-induced diabetes in albino rats [113]. Additionally, the consumption of soluble dietary fibers such as pectin was associated with a reduction of blood glucose levels [114].

All of the mentioned compounds seem to be stable throughout the manufacturing processes of juice production and, therefore, could mediate physiological effects through pomace consumption. The apple pomace matrix seems to increase the tolerance against the negative effects of, for example, phloridzin. Consequently, efforts are taken to find new ways for the inclusion of apple pomace in the recipes of glucose-rich snacks in order to limit their postprandial blood glucose increase [115-117].

\section{Anti-oxidant activity}

Reactive oxygen species (ROS) play an important role in cell signaling cascades. They are highly reactive, and therefore, the concentration, duration, and cellular location of ROS are essential to prevent proteins, lipids, and nucleic acids from major damage. Prolonged imbalances in cellular ROS status are associated with the development of chronic and neurodegenerative diseases [118]. Lambs fed a fattening diet including the addition of $10.91 \%$ of fermented apple pomace showed higher plasma antioxidant activity and higher leukocyte counts than the control group. An observed positive side effect of the apple pomace diet was the enhanced growth of multilayered epithelium and enhanced dimensions of papillae [119].

Wistar rats on native apple pomace diet showed increased serum antioxidant capacity of lipid-soluble substance and an enhanced activity of superoxide dismutase in the hemolysate of erythrocytes [55]. These studies indicate that apple pomace contains compounds able to trigger physiological antioxidant effects.

The effect of apple juice, apple pomace, and apple peel extracts on the redox status and DNA damage of CaCo-2 cells was investigated in vitro [120]. The antioxidant activity of the extracts showed a linear correlation to the content of total low molecular weight polyphenols in the ORAC assay. In the TEAC assay, flavan3-ols and procyanidins were most effective. The apple pomace extract achieved a $53 \%$ reduction of DNA strand breaks measured by the Comet assay and a potent reduction of intracellular ROS level under test concentrations of $1-10 \mu \mathrm{g} / \mathrm{mL}$ and $1-30 \mu \mathrm{g} / \mathrm{mL}$, respectively. Concurrently, the concentration of GPx, a ROS-degrading enzyme that is controlled via the gene regulatory sequence antioxidant responsive element, decreased. The protective effects diminished and even changed to pro-oxidant conditions at higher tested concentrations. Based on these results, the authors hypothesize that nutritional polyphenol concentrations mediate protective effects on intestinal cells via an interaction with cellular ROS-regulating mechanisms. Despite the fact that in vitro ROS scavenging effects of phloretin, epicatechin, and an apple pom- 
ace polyphenol fraction have been postulated, it is more likely that polyphenols induce an intracellular defense mechanism against ROS than have a direct scavenging effect on cellular ROS $[14,121,122]$.

Apple pomace consumption leads to higher concentrations of uric acid/urate in the plasma of healthy volunteers than in volunteers under control diet [87]. In physiological concentrations, uric acids works as a selective plasma antioxidant for, for example, hydroxyl anions and hypochlorous acids or as an oxidizable co-substrate of endothelial enzymes [123]. Permanently elevated levels of uric acid, however, are associated with a growing risk to develop hypertension, gout, and chronic renal disease. The intake of fructose has been associated with an elevation of uric acid plasma levels. During fructose metabolism in the liver, the ketohexokinase catalyzes phosphates and the formed adenosine monophosphate (AMP) is degraded to inosine monophosphate and further to uric acid [124, 125].

Native apple pomace contains high concentrations of fructose. This side effect should be kept in mind if a diet supplementation with apple pomace is intended. However, theoretically, apple pomace products with reduced monosaccharide content and upconcentrated apple pomace polyphenols and fibers could be promising nutritional candidates for the prevention of chronic diseases induced by cellular ROS imbalances.

\section{Anti-inflammatory activity}

Polyphenol-rich fractions from an apple pomace ethanol extract significantly reduced the lipopolysaccharide (LPS)-induced expression of cyclooxygenase (COX)-2 in murine RAW 264.7 macrophage cells. The authors could associate the effect with the compounds procyanidin B2, quercetin, and its 3-O-galactoside. Chlorogenic acid, caffeic acid, and syringin stimulated COX-2 expression, while no effect was observed for (-)-epicatechin, phloridzin, and cinnamic acid [126]. Another study, conducted with a purified subfraction of apple pomace containing up to $72 \%$ procyanidin B2, confirmed the COX-2-inhibiting results [127]. Rana and Bhushan [128] summarized the anti-inflammatory effects of apple polyphenols. Procyanidins, phloretin, kaempferol, and quercetin were identified as potent anti-inflammatory agents. The effect was due to an inhibition of inflammatory enzymes such as COX-2, CYP3A4, transcription factors such as NF-kB, and STAT1, and pro-inflammatory cytokines. Furthermore, ursolic acid exhibited anti-inflammatory potential in vitro and in vivo as summarized by Cargnin and Gnoatto [129].

These studies underline the importance of apple pomace as a source of individual compounds with anti-inflammatory potential. Isolation of these compounds would be needed for therapeutic applications. Their recovery depends not only on the extraction technique but also on the initial compound content at harvest time.

\section{Anti-proliferative activity}

Apple pomaces from six varieties were tested for their antiproliferative activities. All pomace extracts exhibited strong antiproliferative activities in the cervical cancer cell line HeLa. In HT-29 human colon cancer cells, the pomace extracts of Pinova, Iduna and Braeburn apple varieties were especially potent proliferation inhib- itors. The antiproliferative effect could not be correlated to the polyphenol content of the extracts [130].

Two studies from the same author demonstrated the in vitro antiproliferative effects of pectin obtained from apple pomace via supercritical fluid extraction. However, compared to pectin isolated from citrus peels, the growth inhibition rate of apple pomace pectin was $31.3 \%$ lower [131]. Surprisingly, the subcritical water extracted apple pectin showed higher growth inhibition rates of HT-29 cells than commercially available apple pectin [61]. This in turn leads to the presumption that not pectin itself mediates the growth-inhibiting effects, but other compounds that are bound to pectin or associated to it by other mechanisms. Other reviews summarize the antiproliferative effects of apple compounds. Procyanidins and phloretin, as well as ursolic acid, are regarded as potent candidates [128, 129].

Current evidence of antiproliferative activity from apple pomace compounds is based mainly on in vitro studies. In vivo studies are awaited.

\section{Anti-bacterial and anti-viral activity}

Plants evolutionary evolved a sophisticated chemical defense arsenal to combat pathogens, predators, and overgrowth by other plants.

Apple pomace was tested on growth-inhibiting effects against Helicobacter pylori strains, a pathogen that enhances the possibility to develop gastritis, and gastric or duodenal ulcer in infected patients. The $10 \%$ hot-water pomace extract did not exhibit any growth-inhibiting effect in agar diffusion test when administered alone. However, in combination with quince juice and wild or cultivated cranberry juice, synergistic growth-inhibiting effects were observed [132].

Furthermore, the effects of several food-based powders against food-borne pathogens were investigated [133]. A 4\% stock solution of apple skin extract was prepared and diluted to evaluate the bactericidal activity against $E$. coli O157:H7, Lactobacillus monocytogenes RM2199, Salmonella enterica RM1309, and non-MRSA-resistant Staphylococcus aureus 1200. Dilutions of the apple skin extract stock solution, killing $50 \%$ of the aforementioned pathogens, were $>2.7 \%, 1.39 \%, 0.007 \%$, and $0.002 \%$, respectively. The apple skin extract revealed extraordinary growth inhibition of S. aureus strains. The authors elucidated procyanidins and phloridzin as the main compounds in the extract.

Ursolic acid is associated with antimicrobial effects against methicillin-resistant S. aureus, vancomycin-resistant Enterococci, Streptococcus sp., Actinomyces sp., and Listeria monocytogenes [134-137]. Synergistic effects of ursolic and oleanoic acid against Mycobacterium tuberculosis were postulated [138].

Methanol and acetone extracts from apple pomace were used to treat Herpes simplex 1 and 2 (HSV-1, HSV-2) infections in Vero cells. EC $_{50}$ of HSV-1 growth inhibition was $710.9 \mu \mathrm{g} / \mathrm{mL}$ and $576.7 \mu \mathrm{g} / \mathrm{mL}$, respectively. For HSV-2, the $\mathrm{EC}_{50}$ was $629.6 \mu \mathrm{g} / \mathrm{mL}$ and $450.7 \mu \mathrm{g} / \mathrm{mL}$. The $\mathrm{IC}_{50}$ of cell viability was significantly higher with $7281.8 \mu \mathrm{g} / \mathrm{mL}$ for the methanol extract and $5494.9 \mu \mathrm{g} / \mathrm{mL}$ for the acetone extract [139]. A follow-up study investigated the impact of the apple cultivar on the antiviral effect. A significant difference between the effective concentrations of the different cultivars was identified. The cultivar Meana was highly active 
against HSV-1, while the Carrio cultivar showed the best efficacy against HSV-2 infections. The best inhibition rates were achieved when administered at the time point of virus infection. The elucidated mechanism of action was the inhibition of virus adsorption and entry in the host cell. No effects were observed on virus DNA replication for the extracts. Two compounds showed potent antiviral activities, procyanidin B2 against HSV-1 and quercitrin against HSV-2 infections [140].

\section{Hormones}

Human plasma concentration of sulphated dehydroepiandrosteron decreases during apple pomace diet ( $22 \mathrm{~g} /$ day). Sulphated dehydroepiandrosteron is a shared progenitor of male and female sexual hormones and structurally related to bile acids. This leads to the hypothesis that its levels could be decreased via the same mechanism as for the decrease of plasma cholesterol levels during apple pomace diet [87].

\section{Conclusions and Future Perspectives}

Apple pomace is an underutilized waste product of the apple manufacturing industry with potential nutritional and pharmaceutical applications. It is a heterogeneous product impacted by the manufacturing process, the cultivar, and the harvest year, and it represents a source of compounds belonging to numerous structural classes. Despite extensive research of apple pomace, discovery of new compounds is still expected. However, their recovery from the complex matrix remains a challenging task.

Apple pomace extracts, fractions, or isolated compounds thereof have been shown to impact pharmacological targets. Preliminary studies point to promising antioxidative, anti-inflammatory, antibacterial, and antiviral activities. However, the available information to date indicates that the lead structures and mechanisms behind their activity are still to be elucidated. The intake of apple pomace was shown to beneficially influence digesting enzymes, intestinal microbiome, and plasma cholesterol and triglyceride levels. Hence, it could play an important role in the prevention of lifestyle diseases such as type-2 diabetes, hypercholesterolemia, and hyperglyceridemia. Also in this case, the characterization of the beneficial effects and the potential risks must be further investigated in order to achieve a safe and reproducible effect of apple pomace consumption. Future studies of the physiological effects of apple pomace should have an emphasis on the chemical characterization of the material. This would facilitate the correlation of biological activities with pomace constituents and the standardization of the material when intended for therapeutic use.

\section{Acknowledgements}

The work was funded by the Doctoral College "BioProMoTION" at the University of Vienna.
Conflict of Interest

The authors declare no conflict of interest.

\section{References}

[1] European Commission, Director-General for Communication. The European Union Explained: Agriculture. Luxembourg: Publications Office of the European Union; 2014

[2] Development ECAaR. Product report: apple and pears. Available at https://ec.europa.eu/agriculture/sites/agriculture/files/fruit-andvegetables/product-reports/apples-and-pears/expert-group/apples2015-11_fr.pdf. Accessed January 30, 2017

[3] Association EF]. Market Report 2014. Available at http://aijnorg/files/ default/aijn2014-fullpdf. Accessed January 30, 2017

[4] Kara C, Doymaz I. Effective moisture diffusivity determination and mathematical modelling of drying curves of apple pomace. Heat Mass Transf 2015; 51: 983-989

[5] Brushlyanova B, Petrova T, Penov N, Karabadzhov O, Katsharova S. Drying kinetics of different fruit pomaces in a heat pump dryer. Bulg J Agric Sci 2013; 19: 780-782

[6] Almeida-Trasvina F, Medina-Gonzalez S, Ortega-Rivas E, SalmeronOchoa I, Perez-Vega S. Vacuum drying optimization and simulation as a preservation method of antioxidants in apple pomace. J Food Process Eng 2014; 37: 575-587

[7] Jung J, Cavender G, Zhao Y. Impingement drying for preparing dried apple pomace flour and its fortification in bakery and meat products. J Food Sci Technol 2015; 52: 5568-5578

[8] Lavelli V, Corti S. Phloridzin and other phytochemicals in apple pomace: stability evaluation upon dehydration and storage of dried product. Food Chem 2011; 129: 1578-1583

[9] Shalini R. Apple pomace drying: drying characteristics in apple pomace. In: By-Products Utilization. Saarbrücken: LAP Lambert Academic Publishing; 2010

[10] Constenla D, Ponce AG, Lozano JE. Effect of pomace drying on apple pec tin. Lebensm Wiss Technol 2002; 35: 216-221

[11] Sato MF, Rigoni DC, Canteri MHG, Petkowicz CLdO, Nogueira A, Wosiacki G. Chemical and instrumental characterization of pectin from dried pomace of eleven apple cultivars. Acta Sci Agron 2011; 33: 383-389

[12] Guyot S, Marnet N, Sanoner P, Drilleau JF. Variability of the polyphenolic composition of cider apple (Malus domestica) fruits and juices. J Agric Food Chem 2003; 51: 6240-6247

[13] Gazalli H, Malik AH, Jalal H, Afshan S, Mir A. Proximate composition of carrot powder and apple pomace powder. Int J Food Nutr Saf 2013; 3: 25-28

[14] Rana S, Rana A, Gulati A, Bhushan S. RP-HPLC-DAD determination of phenolics in industrial apple pomace. Food Anal Method 2014; 7: 1424-1432

[15] Cho KD, Han CK, Lee BH. Loss of body weight and fat and improved lipid profiles in obese rats fed apple pomace or apple juice concentrate. J Med Food 2013; 16: 823-830

[16] Sato MF, Vieira RG, Zardo DM, Falcao LD, Nogueira A, Wosiacki G. Apple pomace from eleven cultivars: an approach to identify sources of bioactive compounds. Acta Sci Agron 2010; 32: 2935

[17] Dhingra D, Michael M, Rajput H, Patil RT. Dietary fibre in foods: a review. | Food Sci Technol 2012; 49: 255-266

[18] De Vries JA, Voragen AG], Rombouts FM, Pilnik W. Extraction and purification of pectins from alcohol insoluble solids from ripe and unripe apples. Carbohyd Polym 1981; 1: 117-127

[19] Voragen AG], Coenen G], Verhoef RP, Schols HA. Pectin, a versatile polysaccharide present in plant cell walls. Struct Chem 2009; 20: 263-275 
[20] Saha D, Bhattacharya S. Hydrocolloids as thickening and gelling agents in food: a critical review. J Food Sci Technol 2010; 47: 587-597

[21] Li X, He X, Lv Y, He Q. Extraction and functional properties of water-soluble dietary fiber from apple pomace. J Food Process Eng 2014; 37: 293 298

[22] Singhal KK, Thakur SS, Sharma DD. Nutritive value of dried and stored apple pomace and its further processing for improved utilization. Indian J Anim Nutri 1991; 8: 213-216

[23] Smith RB, Lougheed EC, Franklin EW, McMillan I. The starch iodine test for determining stage of maturation in apples. Can J Plan Sci 1979; 59: 725-735

[24] Szalay L, Ordidge M, Ficzek G, Hadley P, Tóth M, Battey NH. Grouping of 24 apple cultivars on the basis of starch degradation rate and their fruit pattern. Hortic Sci 2013; 40: 93-101

[25] Stevenson DG, Domoto PA, Jane J. Structures and functional properties of apple (Malus domestica Borkh) fruit starch. Carbohyd Polym 2006; 63: 432-441

[26] Queji MD, Wosiacki G, Cordeiro GA, Peralta-Zamora PG, Nagata N. Determination of simple sugars, malic acid and total phenolic compounds in apple pomace by infrared spectroscopy and PLSR. Int J Food Sci Technol 2010; 45: 602-609

[27] Gabriel LS, Prestes RA, Pinheiro LA, Barison A, Wosiacki G. Multivariate analysis of the spectroscopic profile of the sugar fraction of apple pomace. Braz Arch Biol Technol 2013; 56: 439-446

[28] Dimick PS, Hoskin JC, Acree TE. Review of apple flavor - state of the art. Crit Rev Food Sci 1983; 18: 387-409

[29] Almosnino AM, Belin JM. Apple pomace: an enzyme system for producing aroma compounds from polyunsaturated fatty acids. Biotechnol Lett 1991; 13: 893-898

[30] Madrera RR, Valles BS. Determination of volatile compounds in apple pomace by stir bar sorptive extraction and gas chromatography-mass spectrometry (SBSE-GC-MS). J Food Sci 2011; 76: C1326-C1334

[31] Fernandez-Moreno JP, Malitsky S, Lashbrooke J, Biswal AK, Racovita RC, Mellerowicz EJ, Jetter R, Orzaez D, Aharoni A, Granell A. An efficient method for medium throughput screening of cuticular wax composition in different plant species. Metabolomics 2016; 12: 73

[32] Brieskorn CH, Wunderer H. Über den chemischen Aufbau der Apfelschale, IV. Pomol- und Pomonsäure. Chem Ber 1967; 100: 1252-1265

[33] Brieskorn $\mathrm{CH}$, Klinger H. Chemical composition of apple peel, II, composition of apple peel triterpenes. Z Lebensm Unters Forsch 1963; 120: 269-273

[34] D’Abrosca B, Fiorentino A, Monaco P, Oriano P, Pacifico S. Annurcoic acid: a new antioxidant ursane triterpene from fruits of $c v$. Annurca apple. Food Chem 2006; 98: 285-290

[35] He X, Liu RH. Triterpenoids isolated from apple peels have potent antiproliferative activity and may be partially responsible for apple's anticancer activity. J Agric Food Chem 2007; 55: 4366-4370

[36] Waldbauer K, Seiringer G, Nguyen DL, Winkler J, Blaschke M, McKinnon R, Urban E, Ladurner A, Dirsch VM, Zehl M, Kopp B. Triterpenoic acids from apple pomace enhance the activity of the endothelial nitric oxide synthase (eNOS). J Agric Food Chem 2016; 64: 185-194

[37] Bock W, Matz J, Täufel K. Bestandteile der aus Apfeltrockentrestern gewinnbaren Triterpenfraktion. Food/Nahrung 1966; 10: 409-412

[38] Zhang S, Ren Y, Liu C, Wang T, Zhao Y, Ren X. Optimization of ultrasonicassisted extraction of total triterpenoids from apple pomace by response surface methodology. Shipin Kexue (Beijing) 2015; 36: 44-50

[39] He QQ, Yang L, Zhang JY, Ma JN, Ma CM. Chemical constituents of goldred apple and their $\alpha$-glucosidase inhibitory activities. J Food Sci 2014; 79: C1970-C1983

[40] Chapman GW jr., Horvat RJ. Determination of nonvolatile acids and sugars from fruits and sweet potato extracts by capillary GLC and GLC/MS. J Agric Food Chem 1989; 37: 947-950
[41] Khan SA, Beekwilder J, Schaart JG, Mumm R, Soriano JM, Jacobsen E, Schouten HJ. Differences in acidity of apples are probably mainly caused by a malic acid transporter gene on LG16. Tree Genet Genomes 2013; 9 : 475-487

[42] Sanoner P, Guyot S, Marnet N, Molle D, Drilleau JP. Polyphenol profiles of French cider apple varieties (Malus domestica sp.). J Agric Food Chem 1999; 47: 4847-4853

[43] Vrhovsek U, Rigo A, Tonon D, Mattivi F. Quantitation of polyphenols in different apple varieties. J Agric Food Chem 2004; 52: 6532-6538

[44] Kolodziejczyk K, Kosmala M, Milala J, Sojka M, Uczciwek M, Krol B, Markowski J, Renard CMGC. Characterisation of the chemical composition of scab-resistant apple pomaces. J Hortic Sci Biotechnol 2010; 84: 89-95

[45] Krawitzky M, Arias E, Peiro JM, Negueruela AI, Val J, Oria R. Determination of color, antioxidant activity, and phenolic profile of different fruit tissue of Spanish 'Verde Doncella' apple cultivar. Int J Food Prop 2014; 17: 2298-2311

[46] Maragò E, lacopini P, Camangi F, Scattino C, Ranieri A, Stefani A, Sebastiani L. Phenolic profile and antioxidant activity in apple juice and pomace: effects of different storage conditions. Fruits 2015; 70: 213 223

[47] Padayachee A, Netzel G, Netzel M, Day L, Zabaras D, Mikkelsen D, Gidley MJ. Binding of polyphenols to plant cell wall analogues - part 2: phenolic acids. Food Chem 2012; 135: 2287-2292

[48] Sanchez-Rabaneda F, Jauregui O, Lamuela-Raventos RM, Viladomat F, Bastida J, Codina C. Qualitative analysis of phenolic compounds in apple pomace using liquid chromatography coupled to mass spectrometry in tandem mode. Rapid Commun Mass Spectrom 2004; 18: 553-563

[49] Ramirez-Ambrosi M, Abad-Garcia B, Viloria-Bernal M, Garmon-Lobato S, Berrueta LA, Gallo B. A new ultrahigh performance liquid chromatography with diode array detection coupled to electrospray ionization and quadrupole time-of-flight mass spectrometry analytical strategy for fast analysis and improved characterization of phenolic compounds in apple products. J Chromatogr A 2013; 1316: 78-91

[50] Ćetković G, Čanadanović-Brunet ], Djilas S, Savatović S, Mandić A, Tumbas V. Assessment of polyphenolic content and in vitro antiradical characteristics of apple pomace. Food Chem 2008; 109: 340-347

[51] Kammerer DR, Kammerer ], Valet R, Carle R. Recovery of polyphenols from the by-products of plant food processing and application as valuable food ingredients. Food Res Int 2014; 65: 2-12

[52] Schieber A, Keller P, Carle R. Determination of phenolic acids and flavonoids of apple and pear by high-performance liquid chromatography. J Chromatogr A 2001; 910: 265-273

[53] Yoruk R, Marshall MR. Physicochemical properties and function of plant polyphenol oxidase: a review. J Food Biochem 2003; 27: 361-422

[54] Pieszka M, Gogol P, Pietras M, Pieszka M. Valuable components of dried pomaces of chokeberry, black currant, strawberry, apple and carrot as a source of natural antioxidants and nutraceuticals in the animal diet. Ann Anim Sci 2015; 15: 475-491

[55] Juskiewicz ], Zary-Sikorska E, Zdunczyk Z, Krol B, Jaroslawska J, Jurgonski A. Effect of dietary supplementation with unprocessed and ethanol-extracted apple pomaces on cecel fermentation, antioxidant and blood biomarkers in rats. Br ] Nutr 2012; 107: 1138-1146

[56] Lavelli V, Kerr W. Apple pomace is a good matrix for phytochemical retention. J Agric Food Chem 2012; 60: 5660-5666

[57] Vityazev FV, Fedyuneva MI, Golovchenko VV, Patova OA, Ipatova EU, Durnev EA, Martinson EA, Litvinets SG. Pectin-silica gels as matrices for controlled drug release in gastrointestinal tract. Carbohyd Polym 2017; 157: 9-20

[58] Klemetsrud T, Jonassen H, Hiorth M, Kjøniksen AL, Smistad G. Studies on pectin-coated liposomes and their interaction with mucin. Colloid Surface B 2013; 103: 158-165 
[59] Bock W, Pose G, Augustat S. On the resorption and hemostatic effects of pectin in the rat. Biochem Z 1964; 341: 64-73

[60] Kartel MT, Kupchik LA, Veisov BK. Evaluation of pectin binding of heavy metal ions in aqueous solutions. Chemosphere 1999; 38: 2591-2596

[61] Wang X, Lu X. Characterization of pectic polysaccharides extracted from apple pomace by hot-compressed water. Carbohydr Polym 2014; 102: 174-184

[62] Wikiera A, Mika M, Grabacka M. Multicatalytic enzyme preparations as effective alternative to acid in pectin extraction. Food Hydrocolloid 2015; 44: 156-161

[63] Franchi ML, Marzialetti MB, Pose GN, Cavalitto SF. Evaluation of enzymatic pectin extraction by a recombinant polygalacturonase (PGI) from apples and pears pomace of Argentinean production and characterization of the extracted pectin. J Food Process Technol 2014; 5: 352

[64] Xue Z, Guo Y, Fu C, Huo T, Yan M, Sun D. Extraction of dietary fiber from apple flesh pomace using hemicellulase. Nat Prod Res 2013; 25: 14741479

[65] Wikiera A, Mika M, Starzyńska-Janiszewska A, Stodolak B. Endo-xylanase and endo-cellulase-assisted extraction of pectin from apple pomace. Carbohyd Polym 2016; 142: 199-205

[66] Emaga TH, Garna H, Paquot M, Deleu M. Purification of pectin from apple pomace juice by using sodium caseinate and characterisation of their binding by isothermal titration calorimetry. Food Hydrocolloid 2012; 29 : 211-218

[67] Guo M, Luo C. Optimization of the preparation of microcrystalline cellulose from apple pomace. Shipin Kexue (Beijing) 2011; 32: 54-58

[68] Liu SW, Li ], Zhao YH, Liu S], Xu HL. Effect of ultra-fine pulverization of dry processing on physical properties of apple pomace fiber. Hebei Keji Shifan Xueyuan Xuebao 2012; 26: 19-25

[69] Rabetafika HN, Bchir B, Aguedo M, Paquot M, Blecker C. Effects of processing on the compositions and physicochemical properties of fibre concentrate from cooked fruit pomaces. Food Bioprocess Technol 2014; 7: 749-760

[70] Ajila CM, Gassara F, Brar SK, Verma M, Tyagi RD, Valero JR. Polyphenolic antioxidant mobilization in apple pomace by different methods of solidstate fermentation and evaluation of its antioxidant activity. Food Bioprocess Technol 2012; 5: 2697-2707

[71] Wang Y, Liu T, Zhang C, Yin L, Wu G. Extraction of flavonoid from apple pomace by cellulase and its antioxidation activities. Shipin Gongye Keji 2010; 31: 252-254

[72] Parmar I, Sharma S, Rupasinghe HPV. Optimization of $\beta$-cyclodextrinbased flavonol extraction from apple pomace using response surface methodology. J Food Sci Technol 2015; 52: 2202-2210

[73] Di L, Hua S, Huijun J. Phloridzin isolated from apple pomace by resin. Adv Mat Res 2013; 621: 121-124

[74] Pieroni A, Quave CL. Traditional pharmacopoeias and medicines among Albanians and Italians in southern Italy: a comparison. J Ethnopharmacol 2005; 101: 258-270

[75] Scherrer AM, Motti R, Weckerle CS. Traditional plant use in the areas of Monte Vesole and Ascea, Cilento National Park (Campania, southern Italy). J Ethnopharmacol 2005; 97: 129-143

[76] Cavender A. Folk medical uses of plant foods in southern Appalachia, United States. J Ethnopharmacol 2006; 108: 74-84

[77] O'Neil CE, Nicklas TA, Fulgoni VL. Consumption of apples is associated with a better diet quality and reduced risk of obesity in children: national health and nutrition examination survey (NHANES) 2003-2010. Nutri J 2015; 14: 48

[78] Hodgson JM, Prince RL, Woodman RJ, Bondonno CP, Ivey KL, Bondonno $\mathrm{N}$, Rimm EB, Ward NC, Croft KD, Lewis JR. Apple intake is inversely associated with all-cause and disease-specific mortality in elderly women. $\mathrm{Br}$ J Nutr 2016; 115: 860-867
[79] Ravn-Haren G, Dragsted LO, Buch-Andersen T, Jensen EN, Jensen RI, Nemeth-Balogh M, Paulovicsova B, Bergstroem A, Wilcks A, Licht TR, Markowski J, Buegel S. Intake of whole apples or clear apple juice has contrasting effects on plasma lipids in healthy volunteers. Eur J Nutr 2013; 52: 1875-1889

[80] Barth SW, Koch TCL, Watzl B, Dietrich H, Will F, Bub A. Moderate effects of apple juice consumption on obesity-related markers in obese men: impact of diet-gene interaction on body fat content. Eur J Nutr 2012; 51: $841-850$

[81] Fotschki B, Jurgonski A, Juskiewicz J, Kolodziejczyk K, Sojka M. Effects of dietary addition of a low-pectin apple fibre preparation on rats. Pol J Food Nutr Sci 2014; 64: 193-199

[82] Abdollahzadeh F, Abdulkarimi R. The effects of some agricultural by products on ruminal fermentation and apparent digestibility of Holstein dairy cow. Life Sci J 2012; 9: 81-85

[83] Brambillasca S, Britos A, Deluca C, Fraga M, Cajarville C. Addition of citrus pulp and apple pomace in diets for dogs: influence on fermentation kinetics, digestion, faecal characteristics and bacterial populations. Arch Anim Nutr 2013; 67: 492-502

[84] Sehm J, Treutter D, Lindermayer H, Meyer HHD, Pfaffl MW. The influence of apple- or redgrape pomace enriched piglet diet on blood parameters, bacterial colonisation, and marker gene expression in piglet white blood cells. Food Nutr Sci 2011; 2: 366-376

[85] Kosmala M, Kolodziejczyk K, Zdunczyk Z, Juskiewicz J, Boros D. Chemica composition of natural and polyphenol-free apple pomace and the effect of this dietary ingredient on intestinal fermentation and serum lipid parameters in rats. J Agric Food Chem 2011; 59: 9177-9185

[86] Licht TR, Hansen M, Bergstrom A, Poulsen M, Krath BN, Markowski J, Dragsted LO, Wilcks A. Effects of apples and specific apple components on the cecal environment of conventional rats: role of apple pectin. BMC Microbiol 2010; 10: 13

[87] Rago D, Gurdeniz G, Ravn-Haren G, Dragsted LO. An explorative study of the effect of apple and apple products on the human plasma metabolome investigated by LC-MS profiling. Metabolomics 2015; 11: 27-39

[88] Heimann E, Nyman M, Pålbrink AK, Lindkvist-Petersson K, Degerman E. Branched short-chain fatty acids modulate glucose and lipid metabolism in primary adipocytes. Adipocyte 2016; 5: 359-368

[89] Ríos-Covián D, Ruas-Madiedo P, Margolles A, Gueimonde M, de los Reyes-Gavilán CG, Salazar N. Intestinal short chain fatty acids and their link with diet and human health. Front Microbio 2016; 7: 185

[90] Huda-Faujan N, Abdulamir AS, Fatimah AB, Anas OM, Shuhaimi M, Yazid $A M$, Loong YY. The impact of the level of the intestinal short chain fatty acids in inflammatory bowel disease patients versus healthy subjects. Open Biochem ] 2010; 4: 53-58

[91] Ohkami H, Tazawa K, Yamashita I, Shimizu T, Murai K, Kobashi K, Fujimaki M. Effects of apple pectin on fecal bacterial enzymes in azoxymethane-induced rat colon carcinogenesis. Jpn J Cancer Res 1995; 86: $523-529$

[92] Kumar A, Chauhan GS. Extraction and characterization of pectin from apple pomace and its evaluation as lipase (steapsin) inhibitor. Carbohydr Polym 2010; 82: 454-459

[93] Becker B, Kuhn U, Hardewig-Budny B. Double-blind, randomized evaluation of clinical efficacy and tolerability of an apple pectin-chamomile extract in children with unspecific diarrhea. Arzneim Forsch 2006; 56: 387-393

[94] Egashira Y, Tsutsui T, Sanada H, Ayano Y. Effect of dietary fibers isolated from apple pomace on cholesterol metabolism in rats. Nippon Eiyo Shokuryo Gakkaishi 1992; 45: 449-452

[95] Leontowicz M, Gorinstein S, Bartnikowska E, Leontowicz H, Kulasek G, Trakhtenberg S. Sugar beet pulp and apple pomace dietary fibers improve lipid metabolism in rats fed cholesterol. Food Chem 2001; 72: $73-78$ 
[96] Garcia-Diez F, Garcia-Mediavilla V, Bayon JE, Gonzalez-Gallego J. Pectin feeding influences fecal bile acid excretion, hepatic bile acid and cholesterol synthesis and serum cholesterol in rats. J Nutr 1996; 126: 1766-1771

[97] Aprikian O, Duclos V, Guyot S, Besson C, Manach C, Bernalier A, Morand C, Rémésy C, Demigné C. Apple pectin and a polyphenol-rich apple concentrate are more effective together than separately on cecal fermentations and plasma lipids in rats. J Nutr 2003; 133: 1860 1865

[98] Sembries S, Dongowski G, Mehrländer K, Will F, Dietrich H. Physiological effects of extraction juices from apple, grape, and red beet pomaces in rats. J Agric Food Chem 2006; 54: 10269-10280

[99] Yao N, He RR, Zeng XH, Huang XJ, Du TL, Cui JC, Hiroshi K. Hypotriglyceridemic effects of apple polyphenols extract via up-regulation of lipoprotein lipase in triton WR-1339-induced mice. Chin J Integr Med 2014; 20: 31-35

[100] Serra AT, Rocha J, Sepodes B, Matias AA, Feliciano RP, de Carvalho A, Bronze MR, Duarte CMM, Figueira ME. Evaluation of cardiovascular protective effect of different apple varieties - correlation of response with composition. Food Chem 2012; 135: 2378-2386

[101] Tenore GC, Campiglia P, Ritieni A, Novellino E. In vitro bioaccessibility, bioavailability and plasma protein interaction of polyphenols from annurca apple (M. pumila Miller cv Annurca). Food Chem 2013; 141 : 3519-3524

[102] Kang HK, Choi HC, Suk CH, Na JC, Kang GH, Bang HT, Park SB, Kim MJ, Seo OS, Lee JE, Kim DW, Kim SH. The effects of dietary fermented fruit pomace and Angelica keiskei Koidz pomace on shelf life, cholesterol and fatty acid composition in broiler. Korean J Food Sci An 2010; 30: 466471

[103] Knekt P, Jarvinen R, Reunanen A, Maatela J. Flavonoid intake and coronary mortality in Finland: a cohort study. BMJ 1996; 312: 478-481

[104] Bondonno CP, Yang X, Croft KD, Considine MJ, Ward NC, Rich L, Puddey IB, Swinny E, Mubarak A, Hodgson JM. Flavonoid-rich apples and nitrate-rich spinach augment nitric oxide status and improve endothelial function in healthy men and women: a randomized controlled trial. Free Radical Biol Med 2012; 52: 95-102

[105] Auclair S, Chironi G, Milenkovic D, Hollman PCH, Renard CMGC, Megnien JL, Gariepy J, Paul JL, Simon A, Scalbert A. The regular consumption of a polyphenol-rich apple does not influence endothelial function: a randomised double-blind trial in hypercholesterolemic adults. Eur J Clin Nutr 2010; 64: 1158-1165

[106] Balasuriya N, Rupasinghe HPV. Antihypertensive properties of flavonoid-rich apple peel extract. Food Chem 2012; 135: 2320-2325

[107] Prentice KJ, Luu L, Allister EM, Liu Y, Jun LS, Sloop KW, Hard AB, Wei L, jia W, Fantus IG, Sweet DH, Sweeney G, Retnakaran R, Dai FF, Wheeler MB. The furan fatty acid metabolite CMPF is elevated in diabetes and induces $\beta$-cell dysfunction. Cell Metab 2014; 19: 653-666

[108] Makarova E, Gornas P, Konrade I, Tirzite D, Cirule H, Gulbe A, Pugajeva I, Seglina D, Dambrova M. Acute anti-hyperglycaemic effects of an unripe apple preparation containing phlorizin in healthy volunteers: a preliminary study. J Sci Food Agric 2015; 95: 560-568

[109] Alvarado F, Crane RK. Phlorizin as a competitive inhibitor of the active transport of sugars by hamster small intestine, in vitro. Biochim Biophys Acta 1962; 56: 170-172

[110] Lee WS, Kanai Y, Wells RG, Hediger MA. The high affinity $\mathrm{Na}+$ /glucose cotransporter. Reevaluation of function and distribution of expression. J Biol Chem 1994; 269: 12032-12039

[111] Faillie JL. Pharmacological aspects of the safety of gliflozins. Pharmacol Res 2017; 118: 71-81

[112] Randhawa V, Sharma P, Bhushan S, Bagler G. Identification of key nodes of type 2 diabetes mellitus protein interactome and study of their interactions with phloridzin. OMICS 2013; 17: 302-317
[113] Rifaai RA, El-Tahawy NF, Saber EA, Ahmed R. Effect of quercetin on the endocrine pancreas of the experimentally induced diabetes in male albino rats: a histological and immunohistochemical study. J Diabetes Metab 2012; $3: 3$

[114] Aller R, de Luis DA, Izaola O, La Calle F, del Olmo L, Fernandez L, Arranz T, Hernandez JMG. Effect of soluble fiber intake in lipid and glucose levels in healthy subjects: a randomized clinical trial. Diab Res Clin $\mathrm{Pr}$ 2004; 65: 7-11

[115] Haghighi M, Rezaei K. Designing an all-apple-pomace-based functional dessert formulation. Br Food J 2013; 115: 409-424

[116] Kohajdova Z, Karovicova J, Magala M, Kuchtova V. Effect of apple pomace powder addition on farinographic properties of wheat dough and biscuits quality. Chem Pap 2014; 68: 1059-1065

[117] Lebesi DM, Tzia C. Effect of the addition of different dietary fiber and edible cereal bran sources on the baking and sensory characteristics of cupcakes. Food Bioprocess Tech 2011; 4: 710-722

[118] Brieger K, Schiavone S, Miller FJ jr., Krause KH. Reactive oxygen species: from health to disease. Swiss Med Wkly 2012; 142: w13659

[119] Rodriguez-Muela C, Rodriguez HE, Arzola C, Diaz-Plascencia D, Ramirez-Godinez JA, Flores-Mariñelarena A, Mancillas-Flores PF, Corral G. Antioxidant activity in plasma and rumen papillae development in lambs fed fermented apple pomace. J Anim Sci 2015; 93: 2357-2362

[120] Bellion P, Digles J, Will F, Dietrich H, Baum M, Eisenbrand G, Janzowski C. Polyphenolic apple extracts: effects of raw material and production method on antioxidant effectiveness and reduction of DNA damage in Caco-2 cells. J Agric Food Chem 2010; 58: 6636-6642

[121] Rezk BM, Haenen GRMM, van der Vijgh WJF, Bast A. The antioxidant activity of phloretin: the disclosure of a new antioxidant pharmacophore in flavonoids. Biochem Bioph Res Co 2002; 295: 9-13

[122] Neiva TJC, Morais L, Polack M, Simões CMO, D’Amico EA. Effects of catechins on human blood platelet aggregation and lipid peroxidation. Phytother Res 1999; 13: 597-600

[123] Becker BF. Towards the physiological function of uric acid. Free Radic Biol Med 1993; 14: 615-631

[124] Rho YH, Zhu Y, Choi HK. The epidemiology of uric acid and fructose. Semin Nephrol 2011; 31: 410-419

[125] Johnson RJ, Nakagawa T, Sanchez-Lozada LG, Shafiu M, Sundaram S, Le M, Ishimoto T, Sautin YY, Lanaspa MA. Sugar, uric acid, and the etiology of diabetes and obesity. Diabetes 2013; 62: 3307-3315

[126] Yue T, Bai X, Zhang H, Yuan Y. Fractionation and anti-inflammatory effects of polyphenol-enriched extracts from apple pomace. Bangl J Pharmacol 2012; 7: 28-32

[127] Zhang H, Ying C. Preparation of procyanidin B2 from apple pomace and its inhibitory effect on the expression of cyclooxygenase-2 in lipopolysaccharide-treated RAW264.7 macrophages. Bangl J Pharmacol 2011; 6: 106-110

[128] Rana S, Bhushan S. Apple phenolics as nutraceuticals: assessment, analysis and application. J Food Sci Techol 2016; 53: 1727-1738

[129] Cargnin ST, Gnoatto SB. Ursolic acid from apple pomace and traditional plants: a valuable triterpenoid with functional properties. Food Chem 2017; 220: 477-489

[130] Cetkovic GS, Savatovic SM, Canadanovic-Brunet JM, Cetojevic-Simin DD, Djilas SM, Tumbas VT, Skerget M. Apple pomace: antiradical activity and antiproliferative action in HeLa and HT29 human tumor cell lines. J BUON 2011; 16: 147-153

[131] Wang X, Chen Q, Lu X. Pectin extracted from apple pomace and citrus peel by subcritical water. Food Hydrocolloid 2014; 38: 129-137

[132] Babarikina A, Nikolajeva V, Babarykin D. Anti-Helicobacter activity of certain food plant extracts and juices and their composition in vitro. Food Nutr Sci 2011; 2: 868-877

[133] Friedman M, Henika PR, Levin CE. Bactericidal activities of health-promoting, food-derived powders against the foodborne pathogens 
Escherichia coli, Listeria monocytogenes, Salmonella enterica, and Staphylococcus aureus. J Food Sci 2013; 78: M270-M275

[134] Wolska KI, Grudniak AM, Fiecek B, Kraczkiewicz-Dowjat A, Kurek A. Antibacterial activity of oleanolic and ursolic acids and their derivatives. Cent Eur J Biol 2010; 5: 543-553

[135] Zhou L, Ding Y, Chen W, Zhang P, Chen Y, Lv X. The in vitro study of ursolic acid and oleanolic acid inhibiting cariogenic microorganisms as well as biofilm. Oral Dis 2013; 19: 494-500

[136] Zou Y, Lee Y, Huh J, Park JW. Synergistic effect of xylitol and ursolic acid combination on oral biofilms. Restor Dent Endod 2014; 39: 288-295

[137] Kurek A, Markowska K, Grudniak AM, Janiszowska W, Wolska KI. The effect of oleanolic and ursolic acids on the hemolytic properties and biofilm formation of listeria monocytogenes. Pol J Microbiol 2014; 63: 21-25

[138] Jiménez-Arellanes A, Luna-Herrera J, Cornejo-Garrido J, López-García S, Castro-Mussot ME, Meckes-Fischer M, Mata-Espinosa D, Marquina B, Torres ], Hernández-Pando R. Ursolic and oleanolic acids as antimicrobial and immunomodulatory compounds for tuberculosis treatment. BMC Complem Altern Med 2013; 13: 258

[139] Suarez B, Alvarez AL, Dineiro Garcia Y, del Barrio G, Picinelli Lobo A, Parra F. Phenolic profiles, antioxidant activity and in vitro antiviral properties of apple pomace. Food Chem 2010; 120: 339-342

[140] Álvarez AL, Melón S, Dalton KP, Nicieza I, Roque A, Suárez B, Parra F. Apple pomace, a byproduct from Asturian cider industry, inhibits Herpes simplex virus types 1 and 2 in vitro replication: study of its mechanisms of action. J Med Food 2012; 15: 581-587

[141] Wijngaard $\mathrm{HH}$, Brunton $\mathrm{N}$. The optimisation of solid-liquid extraction of antioxidants from apple pomace by response surface methodology. J Food Eng 2010; 96: 134-140
[142] Cam M, Aaby K. Optimization of extraction of apple pomace phenolics with water by response surface methodology. J Agric Food Chem 2010; 58: 9103-9111

[143] Candrawinata VI, Golding JB, Roach PD, Stathopoulos CE. Optimisation of the phenolic content and antioxidant activity of apple pomace aqueous extracts. CyTA-J Food 2015; 13: 293-299

[144] Li Z, Ha Y, Li A, Li W, Wang F, Li Q. Optimization of ultrasound-assisted extraction technology of polyphenols from apple pomace by response surface methodology. Sci Agr 2013; 46: 4569-4577

[145] Pingret D, Fabiano-Tixier AS, Bourvellec CL, Renard CMGC, Chemat F. Lab and pilot-scale ultrasound-assisted water extraction of polyphenols from apple pomace. J Food Eng 2012; 111: 73-81

[146] Virot M, Tomao V, Le Bourvellec C, Renard CMCG, Chemat F. Towards the industrial production of antioxidants from food processing byproducts with ultrasound-assisted extraction. Ultrason Sonochem 2010; 17: 1066-1074

[147] Bai X, Yue T, Zhang H, Gao C. Optimization of microwave-assisted extraction technology of polyphenols from apple pomace by response surface method. Zhongguo Shipin Xuebao 2010; 10: 169-177

[148] Chandrasekar V, Martín-González MFS, Hirst P, Ballard TS. Optimizing microwave-assisted extraction of phenolic antioxidants from red delicious and Jonathan apple pomace. J Food Proc Eng 2015; 38: 571-582

[149] Adil iH, Çetin Hi, Yener ME, Bayındırlı A. Subcritical (carbon dioxide + ethanol) extraction of polyphenols from apple and peach pomaces, and determination of the antioxidant activities of the extracts. J Supercrit Fluids 2007; 43: 55-63

[150] Macagnan FT, dos Santos LR, Roberto BS, de Moura FA, Bizzani M, da Silva LP. Biological properties of apple pomace, orange bagasse and passion fruit peel as alternative sources of dietary fibre. Bioact Carbohydr Dietary Fibre 2015; 6: 1-6 